(C) The Author(s), 2021. Published by Cambridge University Press on behalf of The Nutrition Society. This is an Open Access article, distributed under the terms of the Creative Commons Attribution licence (https://creativecommons.org/licenses/by/4.0/), which permits unrestricted re-use, distribution, and reproduction in any medium, provided the original work is properly cited.

\title{
Dietary protein requirements and recommendations for healthy older adults: a critical narrative review of the scientific evidence
}

\author{
Yusuke Nishimura ${ }^{1}$ (1) , Grith Højfeldt ${ }^{2}$, Leigh Breen ${ }^{1}$, Inge Tetens ${ }^{3}$ and Lars Holm ${ }^{1 *}$ \\ ${ }^{1}$ School of Sport, Exercise and Rehabilitation Sciences, University of Birmingham, Birmingham, B15 2TT, UK \\ ${ }^{2}$ Institute of Sports Medicine Copenhagen, Department of Orthopaedic Surgery, Copenhagen University Hospital - Bispebjerg \\ and Frederiksberg, Copenhagen, Denmark \\ ${ }^{3}$ Department of Nutrition, Exercise and Sports, University of Copenhagen, Copenhagen, Denmark
}

\section{Abstract}

Adequate protein intake is essential for the maintenance of whole-body protein mass. Different methodological approaches are used to substantiate the evidence for the current protein recommendations, and it is continuously debated whether older adults require more protein to counteract the age-dependent loss of muscle mass, sarcopenia. Thus, the purpose of this critical narrative review is to outline and discuss differences in the approaches and methodologies assessing the protein requirements and, hence, resulting in controversies in current protein recommendations for healthy older adults. Through a literature search, this narrative review first summarises the historical development of the Food and Agriculture Organization/World Health Organization/United Nations University setting of protein requirements and recommendations for healthy older adults. Hereafter, we describe the various types of studies (epidemiological studies and protein turnover kinetic measurements) and applied methodological approaches founding the basis and the different recommendations with focus on healthy older adults. Finally, we discuss important factors to be considered in future studies to obtain evidence for international agreement on protein requirements and recommendations for healthy older adults. We conclude by proposing future directions to determine 'true' protein requirements and recommendations for healthy older adults.

Key words: Ageing: Sarcopenia: Amino acid: Protein synthesis: Protein breakdown: Net protein balance: Protein turnover: Metabolic adaptation: Energy balance: Protein intake

(Received 1 February 2021; revised 11 October 2021; accepted 14 October 2021)

\section{Introduction}

Adequate protein intake is required for the maintenance of whole-body protein mass. The protein mass in a $70 \mathrm{~kg}$ adult is about $11 \mathrm{~kg}$. Whole-body protein mass maintenance relies on equal rates of protein synthesis and breakdown, resulting in a zero net balance. The constant kinetics of protein synthesis and breakdown of body proteins were originally demonstrated by Schoenheimer and colleagues in $1939^{(1)}$ and were termed protein turnover, which is a modifiable and adaptable process. In adult humans, the daily whole-body protein turnover rate is $5.7 \mathrm{~g} / \mathrm{kg}$ body weight ${ }^{(2)}$, meaning that approximately $400 \mathrm{~g}$ mixed proteins are turned over every day for a $70 \mathrm{~kg}$ adult individual. Behind that number, a large proportion of amino acids are recycled and reutilised for protein synthesis ${ }^{(3-5)}$, whereas some are lost via oxidation for energy production and the formation of urea to scavenge nitrogen ${ }^{(3)}$. Further, nitrogen-containing substances, such as skin, hair, sweat, urine and faeces, are lost from the body. To maintain whole-body protein mass, irreversible loss of amino acids and nitrogen needs to be reconstituted via dietary protein, which founds the basis for the recommended dietary protein intake.

It is well established how much dietary protein should be ingested to account for obligatory nitrogen loss in healthy adults using nitrogen balance methodology ${ }^{(6,7)}$. However, it has continuously been debated ${ }^{(8-14)}$ whether increasing dietary protein intake in older age is an effective strategy to counteract the age-dependent loss of muscle mass ${ }^{(15,16)}$ and strength $^{(17,18)}$, a phenomenon termed sarcopenia ${ }^{(19-21)}$. However, an increase in the dietary protein recommendations for older adults would categorise numerous people as being protein malnourished and thereby increase the incidence of protein malnutrition worldwide. Such a change would challenge nutritional guidelines and nutritional societies and force governments to act with enormous socio-economic consequences. Thus, it is of utmost importance that we adopt a critical approach to the evidence underlying the dietary protein recommendations.

Independent authorities and expert groups have adopted different criteria and evidence from distinct methodological

* Corresponding author: Lars Holm, email 1.holm@bham.ac.uk 
Table 1. Successive protein requirements and recommendations by international groups to ensure nitrogen balance in adults

\begin{tabular}{|c|c|c|c|c|c|}
\hline Report & Age & Methodological approach & $\begin{array}{l}\text { Biological value of } \\
\text { dietary protein (\%) }\end{array}$ & $\begin{array}{l}\text { Average protein } \\
\text { requirements }(\mathrm{g} / \mathrm{kg} / \mathrm{d})\end{array}$ & $\begin{array}{l}\text { Recommendation } / \mathrm{safe} \\
\text { level of intake }(\mathrm{g} / \mathrm{kg} / \mathrm{d})\end{array}$ \\
\hline $\begin{array}{c}\text { League of } \\
\text { Nations } \\
1936^{(22)}\end{array}$ & Adults & - & - & - & 1.0 \\
\hline FAO $1957^{(23)}$ & Adults & $\mathrm{N}$ balance & 80 & 0.53 & 0.66 \\
\hline $\begin{array}{r}\mathrm{FAO} / \mathrm{WHO} \\
1965^{(140)}\end{array}$ & Adults & Factorial & 80 & 0.71 & 0.89 \\
\hline $\begin{array}{l}\mathrm{FAO} / \mathrm{WHO} \\
1973^{(94)}\end{array}$ & Adults (20-39 years) & Factorial & 75 & 0.57 & 0.75 \\
\hline $\begin{array}{l}\mathrm{FAO} / \mathrm{WHO} / \mathrm{UNU} \\
1985^{(95)}\end{array}$ & Adults & $\mathrm{N}$ balance & 100 & 0.75 & 0.75 \\
\hline $\begin{array}{l}\text { FAO/WHO/UNU } \\
2007^{(6)}\end{array}$ & Adults ( $\geq 18$ years) & $\begin{array}{l}\text { Meta-analysis (N-balance } \\
\text { studies) }^{(7)}\end{array}$ & 100 & 0.66 & 0.83 \\
\hline
\end{tabular}

Adopted from NS Scrimshaw ${ }^{(141)}$ and updated.

approaches, resulting in differences in published recommended values of protein recommendations. Consequently, there is currently confusion about the requirements of dietary protein for healthy older adults, both in the scientific community and amongst the general older population, who wish to follow the recommendations. Thus, the purpose of this narrative review is to critically discuss the existing evidence for protein requirements founding the basis for protein recommendations for older adults.

\section{Methodology}

This narrative review was undertaken by: (1) searching PubMed and Google Scholar using keywords related to each topic; (2) screening reference lists for relevant papers; and (3) searching nutritional societies' and authorities' guidelines and references. We specifically included studies conducted in older individuals and only included studies on younger adults when studies in older adults were not available. All articles had undergone peer review and were available in English.

The first part of this review is a summary of the historical development of the protein recommendation with a brief mention of the approaches used and methodologies applied. In the second part, we present and describe in more detail the methodological approaches that found the evidence for determining protein requirements and present the key studies providing data for older adults. Finally, we discuss major factors influencing the requirement for dietary protein and that thus need to be considered in future study designs striving to determine protein requirements. With such consensus, we can accelerate international agreement on protein recommendations for healthy older adults.

\section{Historical development of determining protein requirements and recommendations}

The first official recommendation for protein intake of $1.0 \mathrm{~g} / \mathrm{kg} / \mathrm{d}$, published in 1936 by the League of Nations ${ }^{(22)}$, was set based on observations from practice rather than relying on data from a strict scientific approach. Several joint Food and Agriculture Organization (FAO)/World Health Organization (WHO) expert committees have faced challenges in defining 'protein requirements $^{\text {(23) }}$. In $1957, \mathrm{FAO} / \mathrm{WHO}^{(23)}$ reported their first official protein recommendation, and the latest was reported in $2007^{(6)}$, which thereafter has been challenged by other expert bodies. Table 1 provides an extensive overview of the WHO/ FAO/United Nations University (UNU) recommendations over the years. While the 2007 recommendation defined the protein requirement as being 'the lowest level of dietary protein intake that will balance the losses of nitrogen from the body, and thus maintain the body protein mass, in persons at energy balance with modest levels of physical activity...', it is uncertain whether this amount is sufficient to counteract protein loss in catabolic conditions ${ }^{(24)}$. Even though the Expert Committee rigorously reassessed all available data on protein balance in older people, it was concluded that no studies unequivocally demonstrate that the protein requirement would be higher in older adults when expressed as protein requirement per kg body weight when the purpose was to maintain whole-body protein balance.

Recently, this has led to some expert bodies challenging the protein recommendations for older adults. Table 2 summarises major guidelines from external expert bodies, which, however, are not official recommendations. Although our understanding of protein requirements and recommendations has improved over these 60 years, the outcome measurements, and the methodologies on which the outcome measurement is founded, have not evolved. The discrepancy in protein recommendations is partly due to the lack of a definitive criterion for 'adequate protein', as well as differences in outcome measurements will be discussed. Then, important factors that can impact protein requirements will be reviewed.

\section{Generation of evidence for protein recommendations for older adults}

\section{Protein/nitrogen balance studies}

The nitrogen balance methodology has been used most widely and is considered 'gold standard methodology' to establish the protein requirement ${ }^{(6,7)}$. Whole-body nitrogen balance is determined by measuring or estimating all nitrogen intake (protein intake) and all excretion and loss (skin, hair, sweat, urine and faeces). Positive balance means excess nitrogen intake relative to losses (i.e. protein accretion within the body). Two crucial prerequisites 
Table 2. Protein recommendations by expert bodies to maintain muscle mass and strength in healthy older adults

\begin{tabular}{|c|c|c|c|c|c|}
\hline Report & Age & $\begin{array}{l}\text { Methodological } \\
\text { approach/study design }\end{array}$ & Functional outcomes & Recommendation $(\mathrm{g} / \mathrm{kg} / \mathrm{d})$ & Rationale \\
\hline $\begin{array}{l}\text { Nutrient Reference Values for Australia and } \\
\text { New Zealand } 2006^{(142)}\end{array}$ & $>70$ years & Factorial & $\begin{array}{l}\text { Estimation of the amount } \\
\text { needed for growth and } \\
\text { maintenance on a fat-free } \\
\text { mass basis }\end{array}$ & $\begin{array}{l}\text { Men, } 1.07(81 \mathrm{~g} / \mathrm{d}) \\
\text { Women, } 0.94(57 \mathrm{~g} / \mathrm{d})\end{array}$ & 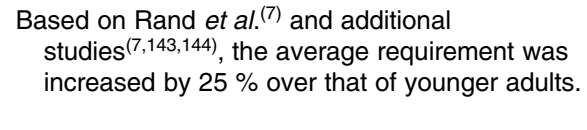 \\
\hline The Nordic Nutrition Recommendations $2012^{(51)}$ & $>65$ years & $\begin{array}{l}\text { Systematic review }^{(145)} \\
\text { (prospective cohort, } \\
\text { case-control and } \\
\text { intervention studies) }\end{array}$ & $\begin{array}{l}\mathrm{N} \text { balance } \\
\text { Muscle mass } \\
\text { Muscle strength } \\
\text { Bone mass } \\
\text { Morbidity } \\
\text { Mortality }\end{array}$ & $\begin{array}{l}1 \cdot 1-1 \cdot 3(15-20 \mathrm{E} \% \text {, and the } \\
\text { protein } \mathrm{E} \% \text { should be } \\
\text { increased with decreasing } \\
\text { energy intake) }\end{array}$ & $\begin{array}{l}\text { The grade of evidence was assessed as } \\
\text { convincing, probable, suggestive and } \\
\text { inconclusive }{ }^{(145)} \text {. The evidence of protein } \\
\text { requirement }(0.66 \mathrm{~g} / \mathrm{kg} / \mathrm{d}) \text { and recommendation } \\
(0.83 \mathrm{~g} / \mathrm{kg} / \mathrm{d}) \text { based on N-balance studies was } \\
\text { assessed as probable. The evidence from } \\
\text { prospective cohort studies in relation to } \\
\text { functional outcomes (e.g. muscle mass and } \\
\text { muscle strength) with a safe intake of at least } \\
1.2-1.5 \mathrm{~g} / \mathrm{kg} / \mathrm{d} \text { was assessed as suggestive to } \\
\text { inconclusive. }\end{array}$ \\
\hline The PROT-AGE Study Group $2013^{(49)}$ & $>65$ years & $\begin{array}{l}\text { Epidemiological studies } \\
\text { Clinical trials }\end{array}$ & $\begin{array}{l}\text { Muscle mass } \\
\text { Muscle strength } \\
\text { Physical function } \\
\text { Muscle protein synthesis }\end{array}$ & $1 \cdot 0-1 \cdot 2$ & $\begin{array}{l}\text { Decrease in anabolic response to protein intake } \\
\text { in older adults; higher protein intake is required } \\
\text { to offset inflammatory and catabolic conditions } \\
\text { often observed in older adults. Both endurance } \\
\text { and resistance exercise were recommended, } \\
\text { and even higher protein intake }(>1.2 \mathrm{~g} / \mathrm{kg} / \mathrm{d}) \\
\text { was recommended those who engage in } \\
\text { exercise. }\end{array}$ \\
\hline The ESPEN Expert Group 2014(50) & $>65$ years & $\begin{array}{l}\text { Epidemiological studies } \\
\text { Clinical trials }\end{array}$ & $\begin{array}{l}\text { Muscle mass } \\
\text { Muscle strength } \\
\text { Physical function } \\
\text { Muscle protein synthesis }\end{array}$ & $1 \cdot 0-1 \cdot 2$ & $\begin{array}{l}\text { Older adults require higher protein owing to } \\
\text { anabolic resistance, low post-prandial amino } \\
\text { acid availability, decreased muscle perfusion, } \\
\text { sarcopenia, and disease-related protein } \\
\text { catabolism. Both endurance and resistance } \\
\text { exercise were recommended. }\end{array}$ \\
\hline
\end{tabular}


for a valid measurement are: (1) metabolic adaptation to any given amount of daily protein intake before conducting the measurements ${ }^{(25-27)}$; and (2) the achievement of energy balance during the period of measurement ${ }^{(7)}$. However, the nitrogen balance methodology has inherent shortcomings: it has been criticised for insufficient sensitivity (i.e. inability to detect small differences between nitrogen intake and excretion) ${ }^{(28)}$. Further, the overestimation of nitrogen intake through food and underestimation of nitrogen loss can lead to erroneous balance measurements.

While nitrogen balance data provide limited mechanistic insight ${ }^{(28,29)}$, Waterlow and colleagues proposed in $1977^{(30)}$ that a relationship between nitrogen balance and protein balance could be expressed at steady state as: flux $(Q)=$ protein synthesis $(S)+$ nitrogen oxidations/excretion $(O)=$ protein breakdown $(B)+$ nitrogen input $(I) \rightarrow Q=I-O=S-B$.

Protein balance calculated as the difference between protein synthesis and breakdown rates provides information about the underlying dynamics of protein kinetics. Protein balance is the rate of either gain or loss of protein per unit time and indicates whether protein mass in the body will quantitatively change over time. Therefore, the prolonged readout of the protein balance data is whole-body protein mass and/or changes herein. Whole-body protein mass, often determined by the surrogate measure of muscle mass, is determined in another set of scientific studies, namely epidemiological studies.

\section{Epidemiological studies of protein intake}

Epidemiological studies, such as cross-sectional and prospective cohort studies, can be used for assessing the association between habitual dietary intake patterns and whole-body/muscle mass ${ }^{(31-42)}$. Epidemiological studies have the strength that adaptation to a given protein intake level would be inherent, yet they often suffer from several confounding factors, limiting the translation into other settings and making it impossible to use the results for assessing protein requirements. Longitudinal intervention studies can be applied to examine the cause-effect relationship and/or dose-response relationship between protein intake and most often physiological and functional outcomes, such as muscle mass, muscle strength and physical function, which is particularly relevant to older adults ${ }^{(43-48)}$.

Cross-sectional studies. The role of protein intake in the maintenance of muscle mass has been investigated across the lifespan in numerous studies (Table 3). A cross-sectional study from the Framingham Offspring Cohort showed a positive association between the total daily and total animal protein intake and muscle mass after adjustment of physical activity and energy intake ${ }^{(42)}$. The association between protein intake and muscle mass became apparent when dividing the cohort into quartiles of protein intake. In men, the difference appeared between the highest $(101.1 \mathrm{~g} / \mathrm{d})$ and the lowest quartile $(64.9 \mathrm{~g} / \mathrm{d})$ for total protein intake. In women, muscle mass differed between the highest and the second-lowest quartile for total protein and animal protein intake $(93.4 \mathrm{~g} / \mathrm{d} \text { versus } 63.1 \mathrm{~g} / \mathrm{d})^{(42)}$. Mangano et $a l .{ }^{(39)}$ examined the third-generation offspring of the original Framingham Heart Study. They divided the cohort into four quartiles based on their protein intake, from the lowest intake (quartile 1) $59 \mathrm{~g} / \mathrm{d}(0 \cdot 8 \mathrm{~g} / \mathrm{kg} / \mathrm{d}$ ) to the highest intake (quartile 4) $129 \mathrm{~g} / \mathrm{d}(1.8 \mathrm{~g} / \mathrm{kg} / \mathrm{d})$. After adjustment for various confounders, including physical activity and energy intake, they found a positive association between protein intake and appendicular lean mass index. A difference was found between the first and the second quartile $(80 \mathrm{~g} / \mathrm{d}$ or $1.1 \mathrm{~g} / \mathrm{kg} / \mathrm{d})$. However, there was no further difference between the first quartile and the third $(99 \mathrm{~g} / \mathrm{d}$ or $1.3 \mathrm{~g} / \mathrm{kg} / \mathrm{d}$ ) and the fourth quartile $(129 \mathrm{~g} / \mathrm{d} \text { or } 1.8 \mathrm{~g} / \mathrm{kg} / \mathrm{d})^{(39)}$. Collectively, crosssectional observational studies suggest that protein intake around the international recommendation $(0.8 \mathrm{~g} / \mathrm{kg} / \mathrm{d}, 60-65 \mathrm{~g} / \mathrm{d}$ in average-sized individuals, $75-80 \mathrm{~kg}$ ) is sub-optimal for the maintenance of muscle mass throughout adult life. They also suggest that muscle mass may be better maintained when protein intake is higher $(80 \mathrm{~g} / \mathrm{d}$ or $1.1 \mathrm{~g} / \mathrm{kg} / \mathrm{d})$ than the international recommendation $(0.83 \mathrm{~g} / \mathrm{kg} / \mathrm{d})$, and that no further beneficial effects on muscle mass are observed beyond this amount, suggesting a non-linear association above this level of intake.

Cross-sectional observational studies including healthy older adults have provided insight into the role of dietary protein intake in the maintenance of muscle mass ${ }^{(31,35,38,41)}$ (Table 3). A positive association was observed between protein intake and muscle mass ${ }^{(31,35)}$. In contrast, it was recently reported that muscle mass did not differ between total daily protein intakes $<0.83, \geq 0.83<1.1$, and $\geq 1.1 \mathrm{~g} / \mathrm{kg}$ adjusted body weight in healthy Danish older individuals ( $\geq 65$ years.), but this might be due to the small sample size $(n=25)$ in protein intake below $0.83 \mathrm{~g} / \mathrm{kg} / \mathrm{d}^{(41)}$. Geirsdottir et al. ${ }^{(35)}$ reported data adjusted for sex, BMI, age and physical activity level and found higher lean body mass in the quartile with the highest protein intake $(1.15-1.92 \mathrm{~g} / \mathrm{kg} / \mathrm{d}$, the fourth quartile) compared with only the first quartile $(0.41-0.75 \mathrm{~g}$ protein $/ \mathrm{kg} / \mathrm{d}, P=0.04)$ and the second quartile $(0.76-0.92 \mathrm{~g} / \mathrm{kg} / \mathrm{d}, P=0.05)$, but not the third quartile. Interestingly, the differences disappeared when correcting for total energy intake, which emphasises the crucial importance of considering energy intake when evaluating the impact of protein intake on the regulation of body composition and especially lean body mass in older adults. Similarly, data by Asp et al. ${ }^{(31)}$ emphasise the dependency between protein and energy intake on muscle and body size as they found that protein intake correlated positively with nutritional status and BMI even when accounting for age, sex and activity level. In support of protein intake as a determining factor for a lean body composition, Gregorio et $a$. $^{(38)}$ divided a total of 387 older women into those ingesting $\geq 0.8 \mathrm{~g} / \mathrm{kg} / \mathrm{d}(n=290)$ and those ingesting $<0.8 \mathrm{~g} / \mathrm{kg} / \mathrm{d}$ $(n=97)$ and found that, although the women in the $\geq 0.8 \mathrm{~g} / \mathrm{kg} / \mathrm{d}$ group had lower lean mass than those in the $<0.8 \mathrm{~g} / \mathrm{kg} / \mathrm{d}$ group, they also had a lower fat mass, resulting in a lower ratio of fat to fat-free mass in the high-protein group. Collectively, some crosssectional observational studies have reported positive associations between protein intake and muscle mass in older adults. However, it seems that, when accounting for nutritional status, energy intake and physical activity, there is limited evidence to recommend that protein intake greater than the international recommendation is beneficial for muscle mass preservation.

Observational studies. Association between protein intake and muscle mass was investigated in an observational study design in healthy older adults ${ }^{(32-34,36,37,40)}$ (Table 4). A positive association 
Table 3. Selected cross-sectional observational studies assessing the association between protein intake and muscle mass

\begin{tabular}{|c|c|c|c|c|c|c|c|c|}
\hline Author, location & $\begin{array}{l}\text { Subjects: men } \\
(M), \text { women }(W)\end{array}$ & $\begin{array}{l}\text { Age, } \\
\text { years }\end{array}$ & $\begin{array}{l}\text { Dietary } \\
\text { assessment }\end{array}$ & $\begin{array}{l}\text { Body } \\
\text { composition } \\
\text { measurement }\end{array}$ & $\begin{array}{l}\text { Average protein } \\
\text { intake }\end{array}$ & Protein intake & Outcomes & Additional information \\
\hline $\begin{array}{l}\text { Sahni et al. } \\
\quad 2015^{(42)} \text {, USA }\end{array}$ & $\begin{array}{l}1139 \mathrm{M}, 1497 \\
\mathrm{~W}\end{array}$ & 29-86 & FFQ & DXA & $\begin{array}{l}\text { M: } 80 \mathrm{~g} / \mathrm{d} \\
W: 76 \mathrm{~g} / \mathrm{d}\end{array}$ & $\begin{array}{l}\text { g/d } \\
\text { Q1: M 64.9, W } 57 \cdot 8 \\
\text { Q2: M 70.8, W } 63 \cdot 1 \\
\text { Q3: M 79.2, W } 73 \cdot 5 \\
\text { Q4: M 101.1, W } 93.4\end{array}$ & $\begin{array}{l}\text { A positive association between protein intake } \\
\text { and leg lean mass }\end{array}$ & \\
\hline $\begin{array}{l}\text { Mangano et al. } \\
2017^{(39)} \text {, USA }\end{array}$ & 2905 M\&W & $19-72$ & FFQ & DXA & $93 \mathrm{~g} / \mathrm{d}$ & $\begin{array}{l}\mathrm{g} / \mathrm{d}(\mathrm{g} / \mathrm{kg} / \mathrm{d}) \\
\text { Q1: } 59(0.8) \\
\text { Q2: } 80(1.1) \\
\text { Q3: } 99(1.3) \\
\text { Q4: } 129(1.8)\end{array}$ & $\begin{array}{l}\text { A positive association between protein intake } \\
\text { and ALM }\end{array}$ & \\
\hline $\begin{array}{l}\text { Geirsdottir et al. } \\
2013^{(35)} \\
\text { Iceland }\end{array}$ & $99 \mathrm{M}, 138 \mathrm{~W}$ & 65-92 & 3-d food record & DXA & $\begin{array}{l}\text { M: } 90.3 \mathrm{~g} / \mathrm{d}, 19.6 \mathrm{E} \% \\
\text { W: } 69.6 \mathrm{~g} / \mathrm{d}, 18.8 \mathrm{E} \\
\%\end{array}$ & $\begin{array}{l}\mathrm{g} / \mathrm{kg} / \mathrm{d} \\
\text { Q1: } 0.63 \\
\text { Q2: } 0.85 \\
\text { Q3: } 1.01 \\
\text { Q4: } 1.36\end{array}$ & $\begin{array}{l}\text { A positive association between protein intake } \\
\text { and LM. Higher LM in Q4 vs Q1 }(2.3 \mathrm{~kg} \\
\text { LM difference) }\end{array}$ & $\begin{array}{l}\text { Significance was not } \\
\text { evident after the } \\
\text { correction with energy } \\
\text { intake }\end{array}$ \\
\hline $\begin{array}{l}\text { Asp et al. } \\
2012^{(31)}, \text { USA }\end{array}$ & $47 \mathrm{M}, 95 \mathrm{~W}$ & $60-88$ & $\mathrm{DHQ}$ & $\mathrm{CC}$ & $15.5 \mathrm{E} \%$ & Protein E \% & $\begin{array}{l}\text { A positive association between protein intake } \\
\text { and CC }\end{array}$ & $\begin{array}{l}\text { A positive association } \\
\text { between beef protein } \\
\text { intake and CC }\end{array}$ \\
\hline $\begin{array}{l}\text { Gregorio et al. } \\
2014^{(38)}, \text { USA }\end{array}$ & $387 \mathrm{~W}$ & $60-90$ & 4-d food record & DXA & $72.2 \mathrm{~g} / \mathrm{d}, 1.1 \mathrm{~g} / \mathrm{kg} / \mathrm{d}$ & $\begin{array}{l}\mathrm{g} / \mathrm{kg} / \mathrm{d} \\
<0.8 \\
\geq 0.8\end{array}$ & $\begin{array}{l}\text { LM was lower in } \geq 0.8 \text { compared to }<0.8 \text {. } \\
\text { Fat-to-Lean Ratio was lower } \\
\text { in } \geq 0.8 \mathrm{~g} / \mathrm{kg} / \mathrm{d}\end{array}$ & \\
\hline $\begin{array}{l}\text { Højfeldt et al. } \\
2020^{(41)} \\
\text { Denmark }\end{array}$ & $98 \mathrm{M}, 86 \mathrm{~W}$ & $65-82$ & 3-d food record & DXA & $\begin{array}{l}82 \cdot 8 \mathrm{~g} / \mathrm{d}, 1.13 \mathrm{~g} / \mathrm{kg} / \mathrm{d} \\
17 \cdot 6 \mathrm{E} \%\end{array}$ & $\begin{array}{l}\mathrm{g} / \mathrm{kg} \mathrm{aBW} / \mathrm{d} \\
<0.83 \\
\geq 0.83-<1.1 \\
\geq 1.1\end{array}$ & $\begin{array}{l}\text { ASMI did not differ between different protein } \\
\text { intakes }\end{array}$ & \\
\hline
\end{tabular}

FFQ, food-frequency questionnaire; E, energy; DXA, Dual-energy X-ray absorptiometry; Q, quartile; DHQ, diet history questionnaire; CC, calf circumference; aBW, adjusted body weight; LM, lean body mass; ALM, appendicular lean body mass; ASMI, appendicular skeletal muscle index. 
Table 4. Selected observational studies assessing the association between protein intake and muscle mass in healthy older adults

\begin{tabular}{|c|c|c|c|c|c|c|c|c|c|}
\hline Author, location & $\begin{array}{l}\text { SubjectsMen (M), } \\
\text { Women (W) }\end{array}$ & $\begin{array}{l}\text { Age, } \\
\text { years }\end{array}$ & $\begin{array}{l}\text { Dietary } \\
\text { assessment }\end{array}$ & $\begin{array}{l}\text { Body } \\
\text { composition } \\
\text { measurement }\end{array}$ & $\begin{array}{l}\text { Follow-up } \\
\text { duration }\end{array}$ & $\begin{array}{l}\text { Baseline average } \\
\text { protein intake }\end{array}$ & Baseline protein intake & Energy intake/balance & Outcomes \\
\hline $\begin{array}{l}\text { Houston et al. } \\
2008^{(32)} \text {, USA }\end{array}$ & $967 \mathrm{M}, 1099 \mathrm{~W}$ & $70-79$ & $\mathrm{FFQ}$ & DXA & 3 years & & $\begin{array}{l}\% \text { of energy }(\mathrm{g} / \mathrm{kg} / \mathrm{d}) \\
\text { Q1: } 11.2(0.7) \\
\text { Q2: } 12.7(0.7) \\
\text { Q3: } 14.1(0.8) \\
\text { Q4: } 15.8(0.9) \\
\text { Q5: } 18.2(1.1)\end{array}$ & & $\begin{array}{l}\text { Higher protein } \\
\text { intake was } \\
\text { associated with } \\
\text { higher } \\
\text { preservation of } \\
\text { LM and aLM }\end{array}$ \\
\hline $\begin{array}{l}\text { Meng et al. } 2009^{(33)} \text {, } \\
\text { Australia }\end{array}$ & $862 W$ & $70-85$ & $\mathrm{FFQ}$ & DXA & 5 years & $\begin{array}{c}81 \mathrm{~g} / \mathrm{d}, 1.2 \mathrm{~g} / \mathrm{kg} / \mathrm{d} \\
19 \mathrm{E} \%\end{array}$ & $\begin{array}{l}\text { g/d, g/kg/d (E \%) } \\
\text { Q1: }<66,0.84(17.7) \\
\text { Q2: 66-87, 1.17 (19.0) } \\
\text { Q3: >87, } 1.64(20.4)\end{array}$ & & $\begin{array}{l}\text { Higher baseline } \\
\text { protein intake } \\
\text { was associated } \\
\text { with higher LM } \\
\text { and aLM at the 5- } \\
\text { years follow-up }\end{array}$ \\
\hline $\begin{array}{l}\text { Scott et al. 2010(34), } \\
\quad \text { Australia }\end{array}$ & $370 \mathrm{M}, 370 \mathrm{~W}$ & $50-79$ & $\mathrm{FFQ}$ & DXA & $\begin{array}{l}1 \cdot 4-4 \cdot 8 \\
\text { years } \\
\text { (mean } \\
2 \cdot 6 \\
\text { years) }\end{array}$ & $87.6 / \mathrm{d}, 1.13 \mathrm{~g} / \mathrm{kg} / \mathrm{d}$ & $\begin{array}{l}<\mathrm{RDI} \\
\geq \mathrm{RDI}\end{array}$ & $\begin{array}{l}\text { Energy intake and BW were } \\
\text { maintained between } \\
\text { baseline and follow-up. } \\
\text { Step counts were } \\
\text { decreased at follow-up } \\
\text { compared with baseline. }\end{array}$ & $\begin{array}{l}\text { Higher protein } \\
\text { intake was } \\
\text { associated with } \\
\text { aLM at baseline } \\
\text { and follow-up }\end{array}$ \\
\hline $\begin{array}{l}\text { McDonald et al. } \\
2016^{(36)} \text {, Denmark }\end{array}$ & $39 \mathrm{M}, 40 \mathrm{~W}$ & $>65$ & Interview & $\begin{array}{l}\text { Bioelectrical } \\
\text { impedance }\end{array}$ & 6 years & $74.6 \mathrm{~g} / \mathrm{d}, 1.07 \mathrm{~g} / \mathrm{kg} / \mathrm{d}$ & $\begin{array}{l}\mathrm{g} / \mathrm{kg} / \mathrm{d} \\
\text { Q1: } 0.61 \\
\text { Q2: } 0.92 \\
\text { Q3: } 0.97 \\
\text { Q4: } 1.26\end{array}$ & & $\begin{array}{l}\text { Higher protein } \\
\text { intake was } \\
\text { associated with } \\
\text { higher } \\
\text { preservation of } \\
\text { LM }\end{array}$ \\
\hline $\begin{array}{l}\text { Chan et al. 2014(37), } \\
\text { China }\end{array}$ & $1411 \mathrm{M}, 1315 \mathrm{~W}$ & $\geq 65$ & $\mathrm{FFQ}$ & DXA & 4 years & $\begin{array}{l}1.3 \text { and } 1.1 \mathrm{~g} / \mathrm{kg} / \mathrm{d} \text { for } \\
M \text { and } W\end{array}$ & $\begin{array}{l}\mathrm{g} / \mathrm{kg} / \mathrm{d} \\
\text { Q1: } \leq 0 \cdot 9 \\
\text { Q2: } 0.91-1 \cdot 2 \\
\text { Q3: } 1 \cdot 1-1 \cdot 6 \\
\text { Q4: } \geq 1 \cdot 61\end{array}$ & & $\begin{array}{l}\text { No association was } \\
\text { found between } \\
\text { protein intake and } \\
\text { ASM }\end{array}$ \\
\hline $\begin{array}{l}\text { Verreijen et al. } \\
2019^{(40)}, \text { USA }\end{array}$ & $749 \mathrm{M}, 812 \mathrm{~W}$ & $70-79$ & FFQ & CT & 5 years & $66.0 \mathrm{~g} / \mathrm{d}, 0.90 \mathrm{~g} / \mathrm{kg} / \mathrm{d}$ & $\begin{array}{l}\mathrm{g} / \mathrm{kg} / \mathrm{d} \\
\text { Q1: } 0.50 \\
\text { Q2: } 0.68 \\
\text { Q3: } 0.85 \\
\text { Q4: } 1.03 \\
\text { Q5: } 1.39\end{array}$ & & $\begin{array}{l}\text { Protein intake was } \\
\text { not associated } \\
\text { with 5-year } \\
\text { change in muscle } \\
\text { cross-sectional } \\
\text { area }\end{array}$ \\
\hline
\end{tabular}

FFQ, food-frequency questionnaire; E, energy; DXA, dual-energy X-ray absorptiometry; Q, quartile; CT, computed tomography; RDI, recommended dietary intake; BW, body weight; LM, lean body mass; ASM, appendicular skeletal muscle mass; aLM, appendicular lean body mass. 
between protein intake and muscle mass was observed in some studies $^{(32-34,36)}$, and these studies concluded that protein intake above the current international recommendation is beneficial for preserving muscle mass in older adults. In all of these studies, baseline average protein intake was higher $(\sim 1.2 \mathrm{~g} / \mathrm{kg} / \mathrm{d})$ than the current international recommendation $(0.83 \mathrm{~g} / \mathrm{kg} / \mathrm{d})^{(32-34,36)}$. In contrast, other studies found that protein intake higher than the current international recommendation does not preserve muscle mass in older adults ${ }^{(37,40)}$. Chan et al. ${ }^{(37)}$ discussed that the null association between protein intake and muscle mass was due in part to the relatively higher protein intake in this cohort $(1.3$ and $1.1 \mathrm{~g} / \mathrm{kg} / \mathrm{d}$ in men and women, respectively). More recently, Verreijen et $a l^{(40)}$ reported that protein intake was not associated with 5 -year changes in muscle mass. The contradicting results from Houston et $a l^{(32)}$ were explained by the methodological approaches used to assess muscle mass. Whilst Houston et $a l .{ }^{(32)}$ employed dual-energy X-ray absorptiometry (DXA), Verreijen et $a l .{ }^{(40)}$ used computed tomography (CT), which is regarded as a more accurate methodology to examine muscle mass. In summary, inconsistent results have been reported in observational studies regarding the association between protein intake above the international recommendation $(0.83 \mathrm{~g} / \mathrm{kg} / \mathrm{d})^{(6)}$. Thus, the newly suggested protein recommendations for healthy older adults of $0.94-1.3 \mathrm{~g} / \mathrm{kg} / \mathrm{d}$ from different authorities and expert groups ${ }^{(49-51,142)}$ can still be questioned.

Intervention studies. Several randomised controlled intervention studies have investigated whether higher protein intake increases muscle mass in older adults ${ }^{(43-48)}$ (Table 5). Some studies were unable to show a beneficial effect of increasing dietary protein intake above their average intake of $\sim 1.2 \mathrm{~g} / \mathrm{kg} / \mathrm{d}$ on muscle accretion or maintenance in older adults $^{(43,44,48)}$. Some studies showing no effect of higher protein intake $(\geq 0 \cdot 8 \mathrm{~g} / \mathrm{kg} / \mathrm{d})$ tended to have a longer study period ( $\geq 1$ year) compared with studies in which an increase in muscle mass was demonstrated $(\sim 24 \text { weeks })^{(43-47)}$, suggesting a possible adaptation effect. Mitchell et al ${ }^{(46)}$ showed that protein intake at 2RDA increased muscle mass compared with RDA in a group of men aged $>70$ years. over a period of 10 weeks. However, the individuals in this study consumed a habitual protein intake of $1 \cdot 1-1.2 \mathrm{~g} / \mathrm{kg} / \mathrm{d}$ on average, and the individuals in the RDA group consumed less protein than the habitual intake during the intervention, which may explain the loss of appendicular lean mass and caused a group difference between RDA and 2RDA. For this study, several limitations can be listed, including that energy balance was not maintained in the RDA group; that lack of a steady metabolic state condition as adaptation was not present for the entire intervention period of 10 weeks; and finally, that no habitual protein intake group was included, which therefore does not allow us to conclude on changes of lean mass without altered protein intake. In summary, null effects of longerterm intervention of elevated dietary protein intake may indicate that metabolic adaptation may level out acute benefits, which was exemplified by a recent study by Højfeldt et al. ${ }^{(52)}$.

\section{Protein turnover kinetic measurement}

Protein turnover kinetic studies are used as more exploratory and mechanistic measurements of the underlying protein turnover kinetic rates. Since the $1970 s^{(53)}$, experimental settings in which the results of muscle protein synthesis (MPS) based on the stable isotope tracer direct incorporation measurement using precursor-product methods ${ }^{(54,55)}$, have established an important basis of knowledge in protein nutrition. In particular, stable isotope tracer and mass spectrometer methodology have advanced our knowledge on MPS in response to amino acids or protein intake ${ }^{(56-58)}$. Experiments with infusion of stable isotope amino acid tracers are usually conducted for $<24 \mathrm{~h}$, and responses to ingestion of amino acids/proteins or mixed meals are measured in a controlled laboratory setting. Experiments are usually designed to measure post-prandial MPS $(\sim 6 \mathrm{~h})$ in response to protein intake while participants are kept in artificial conditions such as fasting and bedridden, often with standardised prior dietary intake. The tissue of interest is often skeletal muscle, with an emphasis on MPS rate. As muscle protein turnover contributes only approximately $25-35 \%$ of whole-body protein turnover in humans ${ }^{(59,60)}$, it is important to take this into consideration if the results from these studies are to be used for estimating protein requirement.

Skeletal muscle protein. Amino acid availability in the circulation is a determinant of MPS stimulation ${ }^{(61)}$, a response that is dose-dependent and saturable even in the presence of sustained elevated circulating amino acids ${ }^{(62-68)}$. Although originally hypothesised ${ }^{(69-71)}$, recent accumulated evidence has concluded that post-absorptive MPS rates do not differ between older and younger individuals ${ }^{(72,73)}$. However, older individuals exhibit a blunted post-prandial MPS response to amino acid/protein intake when compared with younger individuals ${ }^{(63,74-76)}$, which has been termed age-related 'anabolic resistance'. Moore and colleagues synthesised post-prandial MPS data generated in the lab previously ${ }^{(62)}$ and suggested that younger and older individuals are required to consume $0.24 \mathrm{~g} / \mathrm{kg} / \mathrm{meal}$ and $0.4 \mathrm{~g} / \mathrm{kg} / \mathrm{meal}$, respectively, to maximally stimulate MPS, meaning that approximately $70 \%$ more protein is required to maximally stimulate MPS in older individuals compared with younger individuals.

A blunted MPS and, hence, sub-optimal net balance in response to protein feeding and meals could be a plausible driver in the development of sarcopenia. This indicates that older adults need more dietary protein. However, it is important to note that this evidence is derived from acute post-prandial MPS studies in response to high-quality, rapidly digested, mostly animal-based proteins (e.g. egg, whey or casein protein) ${ }^{(62,76)}$.

In addition to the limitations involved in this experimental design, the potential beneficial effects of higher protein intake for muscle and/or whole-body net protein balance or anabolic response are unknown without the simultaneous measurement of muscle or whole-body protein breakdown. Further, the protein recommendation refers to whole-body protein balance $^{(6,7)}$, which is not easily comparable with the responsiveness of skeletal muscle. Hence, we argue that data originating from experimental settings on MPS responsiveness to single dose of protein may lead to misinterpretation and erroneous conclusions on dietary protein requirements in humans at the wholebody level, and therefore cannot be extrapolated to whole-body protein requirements in daily living. 
Table 5. Selected randomised controlled trials investigating the impact of protein intake on muscle mass in healthy older adults

\begin{tabular}{|c|c|c|c|c|c|c|c|c|c|c|}
\hline Author, location & $\begin{array}{l}\text { Study } \\
\text { design }\end{array}$ & $\begin{array}{l}\text { Subjects: } \\
\text { men (M), } \\
\text { women (W) }\end{array}$ & Age, years & $\begin{array}{l}\text { Follow-up } \\
\text { duration }\end{array}$ & $\begin{array}{l}\text { Dietary } \\
\text { assessment }\end{array}$ & $\begin{array}{l}\text { Body } \\
\text { composition } \\
\text { measurement }\end{array}$ & $\begin{array}{l}\text { Baseline average protein } \\
\text { intake }\end{array}$ & Energy intake/balance & Intervention & Outcomes \\
\hline $\begin{array}{l}\text { Mitchell et al. 2017 } \\
\text { New Zealand }\end{array}$ & Parallel & $29 \mathrm{M}$ & $70-81$ & 10 weeks & 3-d food record & DXA & $\begin{array}{l}88-101 \mathrm{~g} / \mathrm{d}, \sim 1 \cdot 2 \mathrm{~g} / \mathrm{kg} / \mathrm{d} \\
14-17 \mathrm{E} \%\end{array}$ & $\begin{array}{l}\text { Energy intake was decreased } \\
\text { in post from pre in RDA } \\
(-440 \mathrm{kcal}) \text { and increased } \\
\text { in } 2 \text { RDA }(+555 \mathrm{kcal}) . \text { BW } \\
\text { was decreased in RDA } \\
(-2.1 \mathrm{~kg}) \text { and } 2 \mathrm{RDA} \\
(-0.5 \mathrm{~kg}) .\end{array}$ & $\begin{array}{l}\text { Protein intake at } \\
\text { RDA }(0.8 \mathrm{~g} / \mathrm{kg} / \mathrm{d}) \\
\text { versus 2RDA } \\
(1.6 \mathrm{~g} / \mathrm{kg} / \mathrm{d})\end{array}$ & $\begin{array}{l}\text { 2RDA increased LM } \\
(+1.49 \mathrm{~kg}) \text { compared } \\
\text { with RDA }(-0.55 \mathrm{~kg})\end{array}$ \\
\hline $\begin{array}{l}\text { Ten Haaf et al. } 2019^{(47)} \text {, } \\
\text { Netherlands }\end{array}$ & Parallel & $93 \mathrm{M}, 21 \mathrm{~W}$ & $67-73$ & 12 weeks & $\begin{array}{r}\text { Two 24-h } \\
\text { recalls }\end{array}$ & DXA & $0.89 \mathrm{~g} / \mathrm{kg} / \mathrm{d}, 16 \mathrm{E} \%$ & $\begin{array}{l}\text { Energy intake was reduced in } \\
\text { post from pre in both protein } \\
(-78 \mathrm{kcal}) \text { and placebo } \\
(-10 \mathrm{kcal}) \text { groups. BW was } \\
\text { decreased in protein } \\
(-0.59 \mathrm{~kg}) \text { and placebo } \\
(-0.15 \mathrm{~kg}) \text { groups. }\end{array}$ & $\begin{array}{l}\text { A total of } 31 \mathrm{~g} \text { of } \\
\text { protein in } 500 \mathrm{ml} \\
\text { milk protein } \\
\text { concentrate drink } \\
\text { per day or } \\
\text { placebo }\end{array}$ & $\begin{array}{l}\text { Protein supplementation } \\
\text { increased LM }(+0.93 \\
\%) \text { compared with } \\
\text { placebo }(+0.44 \%)\end{array}$ \\
\hline $\begin{array}{l}\text { Norton et al. 2016 } \\
\quad \text { Ireland }\end{array}$ & Parallel & $14 \mathrm{M}, 46 \mathrm{~W}$ & $50-70$ & 24 weeks & 4-d food record & DXA & $\begin{array}{c}83-86 \mathrm{~g} / \mathrm{d}, 1 \cdot 2 \mathrm{~g} / \mathrm{kg} / \mathrm{d} \\
16-19 \mathrm{E} \%\end{array}$ & $\begin{array}{l}\text { Energy intake was increased in } \\
\text { post from pre in protein } \\
(+111 \mathrm{kcal}) \text { and placebo } \\
(+116 \mathrm{kcal}) \text { groups. }\end{array}$ & $\begin{array}{l}\text { A total of } 145.4 \mathrm{~g} \text { of } \\
\text { protein per day or } \\
\text { placebo }\end{array}$ & $\begin{array}{l}\text { Protein supplementation } \\
\text { increased LM }(+0.45 \\
\mathrm{kg}) \text { compared with } \\
\text { placebo }(-0.16 \mathrm{~kg})\end{array}$ \\
\hline $\begin{array}{l}\text { Mertz et al. 2021(48), } \\
\text { Denmark }\end{array}$ & Parallel & $184 \mathrm{M}$ and $\mathrm{W}$ & $65-82$ & 1 year & 3-d food record & MRI/DXA & $\begin{array}{c}82.8 \mathrm{~g} / \mathrm{d}, 1.1 \mathrm{~g} / \mathrm{kg} / \mathrm{d} \\
17.6 \mathrm{E} \%\end{array}$ & $\begin{array}{l}\text { Energy intake was increased in } \\
\text { post from pre in whey } \\
(+518 \mathrm{kcal}) \text {, collagen } \\
(+408 \mathrm{kcal}) \text { and placebo } \\
(+949 \mathrm{kcal}) \text {. BW was } \\
\text { increased in whey } \\
(+0.4 \mathrm{~kg}) \text {, collagen } \\
(+0.7 \mathrm{~kg}) \text { and placebo } \\
(+1.2 \mathrm{~kg}) \text {. }\end{array}$ & $\begin{array}{l}\text { A total of }(1) 40 \mathrm{~g} \\
\text { whey protein; } \\
\text { (2) } 40 \mathrm{~g} \text { collagen } \\
\text { protein; or } \\
\text { (3) placebo }\end{array}$ & $\begin{array}{l}\text { Protein supplementation } \\
\text { did not increase LM } \\
\text { and CSA }\end{array}$ \\
\hline $\begin{array}{l}\text { Kerstetter et al. } 2015^{(43)} \text {, } \\
\text { USA }\end{array}$ & Parallel & $30 \mathrm{M}, 178 \mathrm{~W}$ & 75 (mean) & 18 months & 3-d food record & DXA & $72.9 \mathrm{~g} / \mathrm{d}, \sim 1.07 \mathrm{~g} / \mathrm{kg} / \mathrm{d}$ & $\begin{array}{l}\text { Energy intake was decreased } \\
\text { in post from pre in protein } \\
(-120 \mathrm{kcal}) \text { and placebo } \\
(-4 \mathrm{kcal}) \text { groups. BW was } \\
\text { maintained in both groups. }\end{array}$ & $\begin{array}{l}\text { A total of } 45 \mathrm{~g} \text { whey } \\
\text { protein or } \\
\text { placebo }\end{array}$ & $\begin{array}{l}\text { Protein supplementation } \\
\text { did not increase LM }\end{array}$ \\
\hline $\begin{array}{l}\text { Zhu et al. } 2015^{(44)} \text {, } \\
\text { Australia }\end{array}$ & Parallel & $181 \mathrm{~W}$ & $70-80$ & 2 years & 3-d food record & DXA & $76 \mathrm{~g} / \mathrm{d}, 1 \cdot 1-1.2 \mathrm{~g} / \mathrm{kg} / \mathrm{d}$ & $\begin{array}{l}\text { BW was increased in protein } \\
(+0.5 \mathrm{~kg}) \text { and placebo } \\
(+0.4 \mathrm{~kg}) \text {. }\end{array}$ & $\begin{array}{l}\text { A total of } 30 \mathrm{~g} \text { of } \\
\text { skim milk-based } \\
\text { protein } \\
\text { supplement or } \\
\text { placebo }\end{array}$ & $\begin{array}{l}\text { Protein supplementation } \\
\text { did not increase LM }\end{array}$ \\
\hline
\end{tabular}


Table 6. Protein recommendations derived from acute stable isotope tracer incorporation studies in younger and older adults

\begin{tabular}{lccc}
\hline & Younger & Older \\
\hline Dietary protein & \multicolumn{3}{c}{$(\mathrm{g} / \mathrm{kg} \mathrm{BM})$} \\
$\begin{array}{l}\text { Single meal } \\
\text { Day (3-4 meals) }\end{array}$ & 0.24 & & 0.40 \\
Dietary protein & $0.72-0.96$ & & $1.2-1.6$ \\
Single meal & 0.25 & $(\mathrm{~g} / \mathrm{kg} \mathrm{LBM})$ & \\
Day (3-4 meals) & $0.75-1.0$ & & 0.61 \\
Dietary protein & & $(\mathrm{g})^{*}$ & $1.83-2.44$ \\
Single meal & 18 & & 30 \\
Day (3-4 meals) & $54-72$ & & $90-120$ \\
\hline
\end{tabular}

LBM, lean body mass.

* An individual with $75 \mathrm{~kg}$ of body mass (BM).

Values were adopted from Moore et al. ${ }^{(62)}$ determined by Biphasic Linear Regression Model from six independent studies ${ }^{(64,65,146-149)}$.

In summary, studies measuring the acute post-prandial response to protein feeding with the stable isotope tracer technique have led to the hypothesis of age-related muscle anabolic resistance. It is suggested as one of the underlying mechanisms of the development of sarcopenia ${ }^{(62,63,76)}$. Such quantitative data suggest that protein intake of $0.4-0.6 \mathrm{~g} / \mathrm{kg} / \mathrm{meal}$ at three main meals and a snack per day is required to preserve muscle mass in healthy older individuals (Table 6 ), which equates to a protein intake of $<1 \cdot 2-1 \cdot 8 \mathrm{~g} / \mathrm{kg} / \mathrm{d}^{(77)}$

Whole-body protein. More recent investigations have shifted from the use of isolated protein sources to whole foods, the form of protein consumption in everyday life. This shift is due to the interactive effects of protein contained in whole foods with other nutrients and bioactive compounds on muscle and whole-body protein turnover. Studies have primarily focused on MPS in response to beef ${ }^{(78,79)}$, eggs ${ }^{(80,81)}$ and mixed macronutrient meals ${ }^{(82,83)}$. These studies highlighted the importance of considering complex food matrices in the regulation of muscle and whole-body protein turnover.

Previous studies investigating whole-body protein turnover in the context of mixed macronutrient meal intake demonstrated that anabolic response is not limited by protein synthesis ${ }^{(82-84)}$. Deutz and Wolfe ${ }^{(85)}$ advocated that there is no limit to in vivo whole-body protein anabolism when protein is consumed as a part of a mixed macronutrient meal ${ }^{(97,101)}$. More recently, Park et $a l^{(83)}$ showed in healthy older adults $(69.3 \pm 1.8$ years $)$ that there is a higher MPS response following the consumption of a higher protein intake (70 g) compared with moderate (35 g) as part of a mixed macronutrient meal, and a greater whole-body net protein balance in the higher protein intake group due to the suppression of protein breakdown as well as increased protein synthesis (Fig. 1). Importantly, the doses of protein used in this study ( 35 or $70 \mathrm{~g}$ ) were beyond the amount suggested to maximally stimulate MPS in healthy older men ${ }^{(62)}$ (Table 6). Similar findings were also found by the same research group in healthy younger adults ${ }^{(82)}$

The suppression of protein breakdown may also be explained by insulin secretion from non-protein energy sources ${ }^{(86,87)}$. Higher insulin concentration in circulation is observed when protein is consumed in a mixed macronutrient meal $^{(88)}$. A blunted protein breakdown suppression ${ }^{(89)}$ and a failure to achieve positive phenylalanine whole-body net

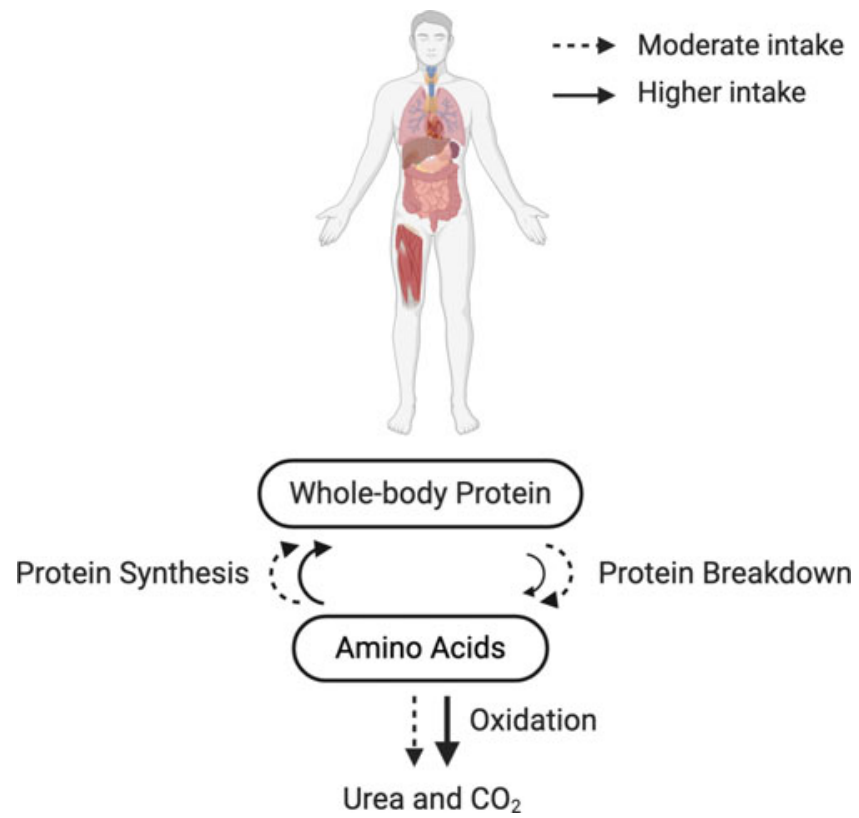

Fig. 1. Whole-body protein turnover in response to the recommended or higher protein intake in a mixed macronutrient meal. Dashed (- -) and solid (-) lines indicate a moderate $(\sim 35 \mathrm{~g} / \mathrm{meal})$ and a higher protein intake $(\sim 70 \mathrm{~g} / \mathrm{meal})$ in a mixed macronutrient meal, respectively. Protein synthesis is saturable at the given amounts of protein intake ${ }^{(82)}$, illustrated by the similar-sized arrows for protein synthesis between the moderate and higher protein intake. Protein breakdown is suppressed by the higher protein intake in a mixed macronutrient meal (illustrated by a smaller solid arrow), resulting in a greater whole-body net protein balance ${ }^{(82,83,85,150)}$. Be aware that a higher protein intake (i.e. surplus of amino acids) also inevitably increases amino acid oxidation and urea excretion ${ }^{(52,117)}$. The results depicted in this figure originate from collective data based on stable isotope tracer studies.

balance ${ }^{(90,91)}$ in response to insulin have been reported in older individuals, which may suggest a difficulty in achieving net positive whole-body protein balance in older individuals in response to mixed macronutrient meal intake. A systematic review and meta-analysis concluded that insulin has a permissive role in MPS, whereas insulin attenuates muscle protein breakdown independently of amino acid availability ${ }^{(92,93)}$. These studies highlight the importance of protein breakdown measurement in the context of a mixed meal intake owing to the suppression of protein breakdown in response to higher protein intake and insulin from non-protein energy sources, resulting in increased whole-body protein anabolism. Moving forward to the justification of the necessity to increase the current international safe level of intake for protein in healthy older adults, the upper limit of protein intake that suppresses protein breakdown, and thus better preserves whole-body protein, should be defined, as highlighted recently by Phillips et al. ${ }^{(14)}$. We argue that whole-body protein turnover data and real-life interventions are more appropriate to extrapolate to protein requirements.

Future directions of protein requirements and recommendations for healthy older adults

\section{Energy balance}

The importance of energy intake in relation to the determination of protein requirement was raised already by the Joint FAO/ 
WHO Ad hoc Expert Committee on Energy and Protein Requirements in $1971^{(94)}$, and later in $1981^{(95)}$. Notably, Young $^{(29)}$ and Millward ${ }^{(96)}$ explored the important concept of protein and energy inter-relation to determine protein requirement. The interaction between energy and nitrogen intake on the maintenance of body nitrogen was well documented by studies on the role of non-protein energy sources (carbohydrate and fat ${ }^{(97-99)}$ using nitrogen balance methodology. For example, Colloway et al. ${ }^{(98)}$ showed back in 1954 that exogenous nitrogen-bearing sources contribute to energy production rather than deposition in the body until adequate energy is consumed. Further, increased non-protein energy intake can also mitigate nitrogen loss in a dose-dependent manner ${ }^{(98)}$. However, the provision of energy attenuates the recruitment of amino acid metabolism for energy turnover and hence retains nitrogen, leading to improvement in nitrogen balance ${ }^{(98)}$. Accordingly, the achievement of energy balance is an underlying assumption for the current internationally recommended protein intake ${ }^{(6)}$.

In recent years, protein metabolism and turnover rate have been studied under a condition of negative energy balance $e^{(100-102)}$ in healthy adults and with an attempt to preserve muscle mass or attenuate muscle loss under negative energy balance by increasing protein intake ${ }^{(103-108)}$. The effect of protein intake above the current recommended safe level of intake $(0.83$ $\mathrm{g} / \mathrm{kg} / \mathrm{d}$ ) on muscle mass maintenance under negative energy balance has been well documented ${ }^{(100,102,109)}$. Evidence indicates that, whilst amino acids contribute more to energy production at negative energy balance ${ }^{(105,110)}$, they are utilised more for de novo protein synthesis when energy balance is achieved. However, evidence is scarce in healthy older individuals, and it is unclear whether increased protein intake during negative energy balance is sufficient to maintain whole-body and muscle protein mass in healthy older adults.

In contrast, limited knowledge is currently available on the impact of positive energy balance on the regulation of protein turnover rates and muscle mass in healthy older adults. Nonetheless, based on knowledge from energy deficit studies $^{(105,110)}$ as well as studies by Woolfson ${ }^{(111)}$ and Calloway and Spector ${ }^{(98)}$, it can be assumed that positive energy balance reduces amino acid oxidation. Accordingly, exogenous amino acids (dietary protein) under such conditions are more efficiently utilised to achieve net positive protein balance. The impact of protein content relative to total energy intake on body composition in younger healthy individuals during overfeeding (18-35 years) was investigated by Bray et al. ${ }^{(112)}$. Participants were divided into $5 \%$ (low protein), $15 \%$ (normal protein) and $25 \%$ (high protein) of total energy intake from protein after a weight-stabilising diet period. Following an 8-week intervention, fat mass was similarly increased in all groups because of overfeeding ( $40 \%$ excess energy from a weight-stabilising diet). However, lean body mass was significantly increased with normal and high protein groups, along with a concomitant increase in resting energy expenditure. These results suggest that energy intake from protein is a sole determinant to increase lean body mass, but not the accretion of fat mass during overfeeding in healthy younger individuals. In this cohort, additional protein may not be required when energy balance is maintained since no impact on lean body mass changes was detected between normal and high protein intake groups ${ }^{(112)}$. Since these findings are limited to healthy younger individuals, further studies are required in healthy older adults. The interaction between energy balance and protein intake in amino acid oxidation, urea excretion and whole-body net protein and nitrogen balance at steady state is illustrated in Fig. 2.

In summary, energy balance in addition to protein intake is a key determinant of protein turnover rates and net protein balance at the whole-body level. However, energy surplus itself does not seem to increase muscle mass, although it reduces amino acid oxidation. Thus, as repeatedly stated in the international reports from WHO/FAO/UNU, energy balance needs to be considered when determining protein requirements. In addition, it is important to highlight that evidence of the interaction between energy balance and protein intake is currently limited to younger individuals, and further evidence is required in healthy older individuals.

\section{Metabolic adaptation to dietary protein intake}

The consideration of metabolic adaptation to any given amount of protein intake is required for a valid measure of protein requirement. Protein turnover in the splanchnic area as well as in the periphery is adaptable to a given amount of protein intake ${ }^{(25-27)}$. Metabolic adaptation covers processes affecting the utilisation and fate of amino acids, primarily in the splanchnic area. A prolonged exposure to a given amount of protein intake forces enzyme and transporter levels to change accordingly to handle the amino acid availabilities. Hence, metabolic adaptation to a given protein intake level is a fundamental prerequisite when estimating protein requirements. In physiology, adaptation covers conditions where achievement of a steady state can be obtained after adjustments of metabolism and physiological function ${ }^{(113,114)}$. In contrast, when conditions are too extreme for metabolic pathways to adjust sufficiently, but rather continuously lag behind and the changes are beyond the range of adaptation, the condition is defined as accommodation ${ }^{(115)}$.

Recent emerging evidence highlights the mechanisms of adaptation to a protein intake higher than the current safe level of dietary protein intake. For example, Gorissen et al. ${ }^{(116)}$ measured the availability of dietary protein using intrinsically labelled whey protein. In this study, older individuals $(62 \pm 1$ years) were habituated to a protein intake of either $0.7 \mathrm{~g} / \mathrm{kg} / \mathrm{d}$ (LOW) or $1.5 \mathrm{~g} / \mathrm{kg} / \mathrm{d}(\mathrm{HIGH})$ for 2 weeks from a habitual intake of protein at $1.0 \mathrm{~g} / \mathrm{kg} / \mathrm{d}$. Interestingly, no group differences were noted in either post-absorptive or post-prandial MPS, and more intrinsically labelled whey protein was available in the circulation in LOW (61\%) in comparison with HIGH (56\%). This was in agreement with our recent study where responses in amino acid and protein metabolism were investigated after habituation to a protein intake of $>2 \cdot 1 \mathrm{~g} / \mathrm{kg}$ lean body mass $(\mathrm{LBM}) / \mathrm{d}(0.82 \mathrm{~g} / \mathrm{kg} / \mathrm{d})$ and a protein intake of $1.1 \mathrm{~g} / \mathrm{kg}$ $\mathrm{LBM} / \mathrm{d}(1.76 \mathrm{~g} / \mathrm{kg} / \mathrm{d})$ for $20 \mathrm{~d}$ in older men $(65-70 \text { years })^{(52)}$. These findings suggest that exogenous amino acids are directed less effectively into the circulation when habituated to a high protein intake. Habituation to a high protein intake also resulted in a diminished post-prandial synthesis rate of plasma proteins and a more negative overnight fasted whole-body net protein 


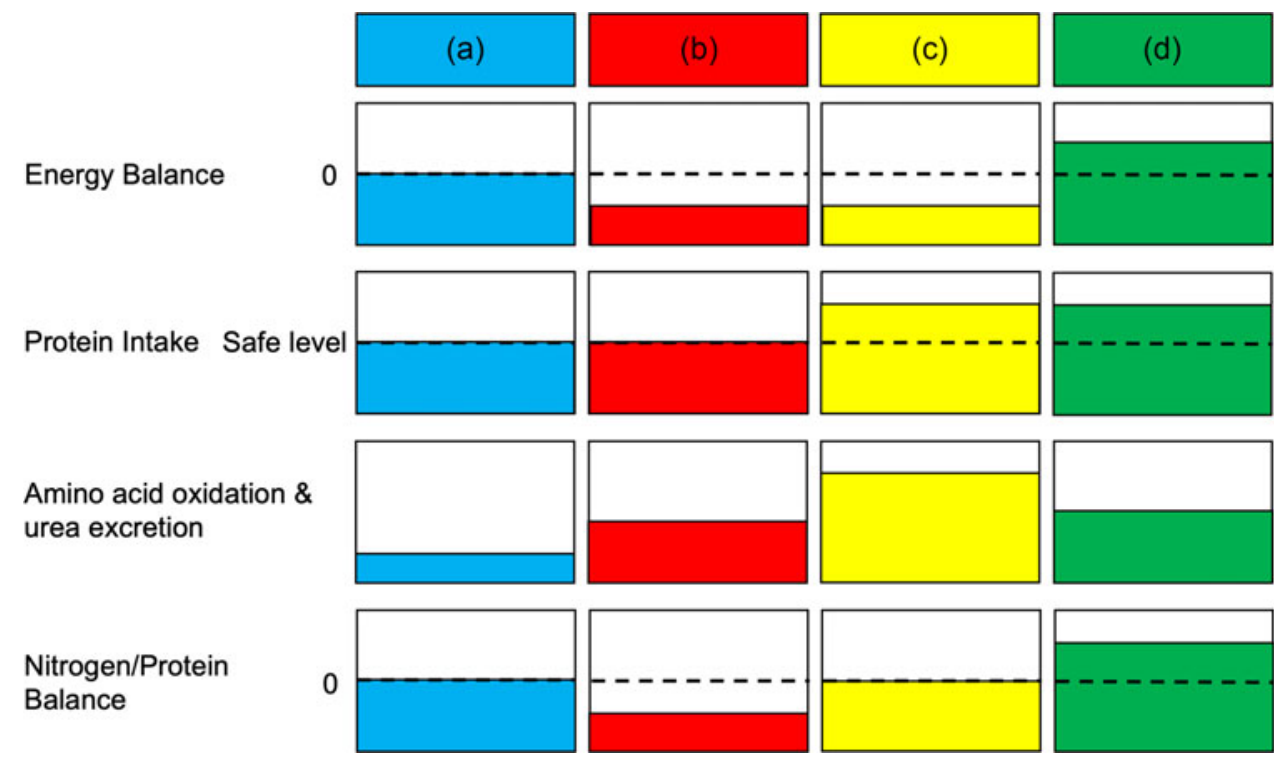

Fig. 2. Interaction between energy and protein intake on amino acid oxidation, urea excretion, and whole-body net nitrogen and protein balance during the condition of adaptation. In each column, relative energy balance, protein intake, amino acid oxidation and urea excretion, and nitrogen/protein balance are expressed. For energy balance and nitrogen/protein balance, 0 (dashed line) indicates that a balance is maintained. Safe intake (dashed line) in protein intake shows the protein intake recommended by WHO/FAO/UNU $(0.83 \mathrm{~g} / \mathrm{kg} / \mathrm{d})$. (a) The column indicates zero whole-body net nitrogen and protein balance at the safe level of intake for protein recommended by WHO/FAO/UNU under energy balance condition ${ }^{(6)}$. (b) and (c) indicate a negative energy balance condition. (b) The column shows the protein intake at the safe level of intake, but amino acid oxidation and urea excretion are increased under a negative energy balance condition, leading to negative whole-body net protein and nitrogen balance during negative energy balance ${ }^{(105,110)}$. (c) The column demonstrates that an increased protein intake (>0.83 $\left.\mathrm{g} / \mathrm{kg} / \mathrm{d}\right) \mathrm{preserves}$ whole-body net protein and nitrogen balance whilst increasing amino acid oxidation and urea excretion under a negative energy balance condition ${ }^{(104,107,108)}$. (d) The column denotes that amino acid oxidation and urea excretion are reduced under a positive energy balance condition with an increased protein intake ( $>0.83 \mathrm{~g} / \mathrm{kg} / \mathrm{d}$ ), resulting in positive whole-body net protein and nitrogen balance ${ }^{(112)}$.

balance, suggesting a less effective utilisation of exogenous amino acids for protein synthesis. In accordance, Walrand et $a{ }^{(117)}$ demonstrated that higher protein intake showed a post-absorptive catabolic state, as demonstrated by higher amino acid oxidation and whole-body protein turnover, without changing MPS in both younger ( $24 \pm 1$ years) and older individuals $(70 \pm 2$ years) when higher protein intake $(3.0 \mathrm{~g} / \mathrm{kg}$ fat-free mass) was compared with 'usual' protein intake $(1.5 \mathrm{~g} / \mathrm{kg}$ fat-free mass) over $10 \mathrm{~d}$. However, nitrogen balance was improved in the higher protein intake group, which may suggest insufficient time to adapt to the new protein intake level in this study. Evidence emphasises the necessity of allowing time for metabolism to adapt to increased protein intake. Further evidence adopting study designs and methodological approaches that can account for metabolic adaptation is required to obtain a meaningful value for protein requirement, which can then be translated into recommendations.

Metabolic adaptation to changes in protein intake may explain the null findings when an intervention was performed long enough to achieve adaptation ${ }^{(26,52,118,119)}$. In other words, sustained increases in muscle mass would not be achieved when individuals chronically consume dietary protein levels higher than habitual protein intake level. Baseline protein intake level might be a key determinant of the beneficial effect of dietary protein intervention on muscle mass gain in healthy older adults in a randomised controlled intervention study. This notion was highlighted previously ${ }^{(120)}$ and is supported by a meta-analysis conducted by Ten Haaf et al. ${ }^{(121)}$, where they assessed the impact of protein supplementation on lean body mass, muscle strength and physical performance in community-dwelling older individuals. Protein supplementation is not beneficial for those outcome measures when sufficient habitual protein intakes are already consumed in non-frail older individuals.

A recent meta-analysis including a total of 8107 communitydwelling older individuals from cohorts in the Netherlands, the UK, Canada and the United States showed that the prevalence of protein intake lower than the currently recommended level of $0.8 \mathrm{~g} / \mathrm{kg}$ adjusted body weight $/ \mathrm{d}$ is $14-30 \%{ }^{(122)}$. Thus, this low habitual protein intake group may be a more relevant target group for protein supplementation intervention with a concomitant focus on ensuring energy requirements. However, when the purpose is to determine whether a higher than currently recommended protein intake is favourable for muscle and whole-body protein mass, healthy older individuals habitually consuming protein around the current safe level of intake should be the target group and not the low-habitual intake group. Collectively, more randomised controlled intervention studies are required to conclude whether the newly suggested higher protein intakes from several expert groups above the safe level of intake at $0.83 \mathrm{~g} / \mathrm{kg} / \mathrm{d}$ have a favourable impact on muscle mass in healthy older adults consuming protein at the current international recommendation.

\section{Protein quality}

Protein quality is an overall measure of the ability of a protein source to meet the metabolic demand and is defined in terms of biological value (i.e. the fraction of amino acids absorbed by the gut from a food that is subsequently retained by the body). Biological value is 
expressed in terms of indispensable amino acid patterns relative to the requirement ${ }^{(6)}$.

The concept of protein quality can be learned from the Ideal Protein Concept developed in the late 1950s by Mitchell ${ }^{(123)}$ and Scott ${ }^{(124)}$. The Ideal Protein Concept is defined as the exact amounts of amino acids needed for optimal growth, meaning that it causes neither amino acid deficiency nor surplus availability. Thus, the Ideal Protein Concept is an effective way to define minimum protein in the diet to meet amino acid requirements for metabolic demands in animals. For example, the Ideal Protein Concept initially attempted to provide diets containing the exact balance of essential amino acids based on the composition of eggs and casein for the maximal growth and production performance of chickens. However, non-essential amino acids were not considered in the concept. Re-evaluations in the area of optimal animal feed for growth have found that the provision of non-essential amino acids is also required for development, growth, survival, reproduction and health ${ }^{(125,126)}$. Consequently, the provision of non-essential amino acids will lower the required amounts of some essential amino acids as they will not be needed as precursors for de novo synthesis of non-essential amino acids. Therefore, protein quality must also be considered when discussing protein requirements and should be reflected in the overall recommendations ${ }^{(127)}$, including the consideration of non-essential amino acids ${ }^{(128)}$.

Digestibility of amino acids is an integrated part of the protein quality measure. FAO developed the Protein Digestibility Corrected Amino Acid Score (PDCAAS) as a measure of overall nitrogen digestibility considering loss in faecal matter. This concept had some inherent limitations ${ }^{(129)}$ that were later attempted to be overcome by replacing it with the new term Digestible Indispensable Amino Acid Score (DIAAS), which includes: (1) the adoption of ileal amino acid digestibility; (2) abrogation of truncation of scores; (3) taking the influence of food processing into account; and (4) the use of individual amino acid digestibility.

The earlier protein requirements and recommendations by the WHO/FAO/UNU specified protein quality, whereas the current recommendations refer to 'high-quality protein' with a biological value of 100, usually an animal source protein (Table 1). Animal-based proteins are generally accepted as high-quality protein owing to better essential amino acid profile and higher digestibility (approximately 100) as compared with plant-based proteins (ranging from 80 to 85$)^{(127,130)}$. Plant-based proteins are less digestible due to existence of dietary fibre and compounds that inhibit enzymatic protein digestion.

Despite the accumulated evidence that supports muscle protein anabolic response by the ingestion of animal-based proteins, plant-based proteins have attracted more attention due to their environmental sustainability and population health benefits ${ }^{(131)}$. Recently, Burd et al. ${ }^{(132)}$ discussed that consideration of protein quality is critical when protein recommendations are determined in relation to environmental considerations (e.g. managing greenhouse gas emissions, land and water use, and loss of biodiversity). Evidence shows that greenhouse gas emission is lower in plant-based proteins as compared with animal-based proteins ${ }^{(131)}$. Growing evidence has shown health benefits of vegetarian and vegan diets, including lower incidence and mortality from ischemic heart disease and lower incidence of cancer ${ }^{(133)}$. However, the effects of vegetarian and vegan diets on overall mortality rates are currently unclear ${ }^{(134)}$.

The impact of vegan and vegetarian diets on muscle mass maintenance in healthy older adults is an important consideration. Cross-sectional studies have shown that total protein and animal protein intakes, but not plant protein intake, are positively associated with muscle mass index in older women ${ }^{(135)}$. Results from a longitudinal observational study show that higher intakes of total protein and animal-based protein are associated with a reduced loss of lean mass over 3 years of follow-up, whereas plant-based protein intake is not associated with lean mass with the fully adjusted models in older adults ${ }^{(32)}$. These data suggest that plant-based diet may not be favourable for muscle mass maintenance in older adults. However, we argue that more studies are required to fully elucidate this association.

Several strategies have been proposed by Gorissen and Witard $^{(136)}$ to overcome the perceived inferior anabolic properties of plant-based proteins. Firstly, the doses of plant-based protein intake can be increased; secondly, several plant-based protein sources can be mixed in a meal and in the whole diet to overcome any deficiency of a single essential amino acid; thirdly, co-ingestion of leucine can be added as an anabolic stimulant; and fourthly, muscle anabolic sensitivity can be enhanced by physical activity or by other means (e.g. by providing fish oil-derived $n-3$ polyunsaturated fatty acids in the meal or diet).

Considering potential metabolic roles of individual amino acids is also important. This notion has been exemplified by a study demonstrating that increasing the proportion of leucine to mixed amino acids without altering total amino acids content overcomes anabolic resistance in older individuals ${ }^{(137)}$. Furthermore, addition of leucine to a sub-optimal amount of protein is hypothesised to optimise anabolic response. For example, Wall et al. ${ }^{(138)}$ demonstrated a greater post-prandial MPS following the consumption of $20 \mathrm{~g}$ casein protein with $2.5 \mathrm{~g}$ of crystalline leucine compared with no leucine in older men ( $74 \pm 1$ years), indicating that modifying and/or supplementing specific amino acid content might be an effective and practical strategy to improve anabolic response. This is particularly relevant to older individuals, whose energy requirement and appetite are decreasing with advancing age ${ }^{(139)}$. Protein requirement that maintains whole-body and muscle protein mass can be achieved with lower total protein intake by optimising protein quality, which is also an important consideration for environmental issues. However, evidence is required on whether the modification of protein quality is a feasible approach to maintain whole-body protein balance in healthy older adults.

\section{Conclusions}

Considering the historical development of protein requirements and the use of various research methodologies to obtain scientific evidence for assessing protein requirements to create recommendations, we found that the previously used wholebody nitrogen balance methodology is challenged by methods 
evaluating whole-body and/or muscle mass and whole-body and/or muscle protein turnover rate as criteria. The newly suggested protein recommendations $(0.94-1.3 \mathrm{~g} / \mathrm{kg} / \mathrm{d})$ formulated by some authorities and expert groups target muscle mass maintenance instead of whole-body protein mass as their primary outcome criterion.

To close the knowledge gap between protein requirements for maintaining both muscle mass and whole-body mass, we identified that future research should assess the degree of agreement between these different, though related, outcome measures based on distinct methodologies. There is a strong need for prospective longitudinal studies with frequent monitoring of reliable dietary intake and concurrent measurements of whole-body protein mass and muscle mass with multiple methodologies. These would include short-term measurements (e.g. muscle and whole-body protein balance, kinetic rates, and nitrogen fluxes) and longer-term measurements (ensuring metabolic adaptation and energy balance) with consideration of protein quality. Also evaluating clinically relevant outcomes, such as muscle strength and function, physical function, body composition and metabolic health parameters, would be preferable. Such a holistic experimental approach would support establishing an agreement between muscle and whole-body protein mass maintenance, and thereby reveal the 'true' and healthy dietary protein requirements and recommendations for healthy older adults.

\section{Acknowledgements}

Y.N. is supported by the Postgraduate Research Scholarship Fund at the University of Birmingham.

Y.N.: Conceptualisation, Visualisation, Writing - original draft, Writing - review and editing. G.H.: Writing - review and editing. L.B.: Writing - review and editing. I.T.: Conceptualisation, Writing - review and editing. L.H.: Conceptualisation, Writing review and editing. All authors read and approved the final manuscript.

The authors have no conflicts of interest.

\section{References}

1. Schoenheimer R, Ratner S \& Ritten-Berg D (1939) Studies in protein metabolism. 10. The metabolic activity of body proteins investigated with 1(-)-leucine containing two isotopes. J Biol Chem 130, 703-732.

2. Waterlow JC (1981) Nutrition and protein turnover in man. $\mathrm{Br}$ Med Bull 37, 5-10.

3. Wolfe RR (2017) Branched-chain amino acids and muscle protein synthesis in humans: myth or reality? J Int Soc Sports Nutr 14, 30.

4. Holm L, Dideriksen K, Nielsen RH, et al. (2019) An exploration of the methods to determine the protein-specific synthesis and breakdown rates in vivo in humans. Physiol Rep 7, e14143.

5. Nishimura Y, Musa I, Holm L, et al. (2021) Recent advances in measuring and understanding the regulation of exercisemediated protein degradation in skeletal muscle. Am J Physiol Cell Physiol 321, C276-C287.
6. World Health Organization \& United Nations University (2007) Protein and Amino Acid Requirements in Human Nutrition. Geneva: World Health Organization.

7. Rand WM, Pellett PL \& Young VR (2003) Meta-analysis of nitrogen balance studies for estimating protein requirements in healthy adults. Am J Clin Nutr 77, 109-127.

8. Traylor DA, Gorissen SHM \& Phillips SM (2018) Perspective: protein requirements and optimal intakes in aging: are we ready to recommend more than the recommended daily allowance? Adv Nutr 9, 171-182.

9. Courtney-Martin G, Ball RO, Pencharz PB, et al. (2016) Protein requirements during aging. Nutrients $\mathbf{8}, 492$.

10. Campbell WW, Johnson CA, McCabe GP, et al. (2008) Dietary protein requirements of younger and older adults. Am J Clin Nutr 88, 1322-1329.

11. Wolfe RR, Miller SL \& Miller KB (2008) Optimal protein intake in the elderly. Clin Nutr 27, 675-684

12. Millward DJ, Fereday A, Gibson N, et al. (1997) Aging, protein requirements, and protein turnover. Am J Clin Nutr 66, 774-786.

13. Volpi E, Campbell WW, Dwyer JT, et al. (2013) Is the optimal level of protein intake for older adults greater than the recommended dietary allowance? J Gerontol A Biol Sci Med Sci 68 , 677-681.

14. Phillips SM, Paddon-Jones D \& Layman DK (2020) Optimizing adult protein intake during catabolic health conditions. $A d v$ Nutr 11, S1058-S1069.

15. Gallagher D, Visser M, De Meersman RE, et al. (1997) Appendicular skeletal muscle mass: effects of age, gender, and ethnicity. J Appl Physiol 83, 229-239.

16. Janssen I, Heymsfield SB, Wang ZM, et al. (2000) Skeletal muscle mass and distribution in 468 men and women aged 18-88 year. J Appl Physiol 89, 81-88.

17. Goodpaster BH, Park SW, Harris TB, et al. (2006) The loss of skeletal muscle strength, mass, and quality in older adults: the health, aging and body composition study. J Gerontol A Biol Sci Med Sci 61, 1059-1064.

18. Delmonico MJ, Harris TB, Visser M, et al. (2009) Longitudinal study of muscle strength, quality, and adipose tissue infiltration. Am J Clin Nutr 90, 1579-1585.

19. Rosenberg IH (1997) Sarcopenia: origins and clinical relevance. J Nutr 127, 990s-991s.

20. Cruz-Jentoft AJ \& Sayer AA (2019) Sarcopenia. Lancet 393, 2636-2646.

21. Bülow J, Ulijaszek SJ \& Holm L (2019) Rejuvenation of the term sarcopenia. J Appl Physiol 126, 255-256.

22. League of Nations (1936) The Problem of Nutrition. Report on the Physiological Bases of Nutrition Drawn Up by the Technical Commission of the Health Committee. Geneva: Forgotten Books.

23. Joint $\mathrm{FAO} / \mathrm{WHO} / \mathrm{UNU}$ Expert Consultation on Protein Requirements in Human Nutrition, Food and Agriculture Organization of the United Nations, World Health Organization, et al. (1958) Protein Requirements: Report of the FAO Committee. FAO Nutritional Series no. 16. Geneva: WHO.

24. Wolfe RR (2018) The 2017 Sir David P Cuthbertson lecture. Amino acids and muscle protein metabolism in critical care. Clin Nutr 37, 1093-1100.

25. Millward DJ, Price GM, Pacy PJ, et al. (1991) Whole-body protein and amino acid turnover in man: what can we measure with confidence? Proc Nutr Soc 50, 197-216.

26. Millward DJ (1998) Metabolic demands for amino acids and the human dietary requirement: Millward and Rivers (1988) revisited. J Nutr 128, 2563S-2576S. 
27. Price GM, Halliday D, Pacy PJ, et al. (1994) Nitrogen homoeostasis in man: influence of protein intake on the amplitude of diurnal cycling of body nitrogen. Clin Sci 86, 91-102.

28. Young VR (1986) Nutritional balance studies: indicators of human requirements or of adaptive mechanisms? J Nutr 116, 700-703.

29. Young VR, Yu YM \& Fukagawa NK (1991) Protein and energy interactions throughout life. Metabolic basis and nutritional implications. Acta Paediatr Scand Suppl 373, 5-24.

30. Waterlow JC, Golden M \& Picou D (1977) The measurement of rates of protein turnover, synthesis, and breakdown in man and the effects of nutritional status and surgical injury. Am J Clin Nutr 30, 1333-1339.

31. Asp M, Richardson J, Collene A, et al. (2012) Dietary protein and beef consumption predict for markers of muscle mass and nutrition status in older adults. J Nutr Health Aging 16, 784-790.

32. Houston DK, Nicklas BJ, Ding J, et al. (2008) Dietary protein intake is associated with lean mass change in older, community-dwelling adults: the health, aging, and body composition (Health ABC) study. Am J Clin Nutr 87, 150-155.

33. Meng X, Zhu K, Devine A, et al. (2009) A 5-year cohort study of the effects of high protein intake on lean mass and BMC in elderly postmenopausal women. J Bone Miner Res 24, $1827-1834$.

34. Scott D, Blizzard L, Fell J, et al. (2010) Associations between dietary nutrient intake and muscle mass and strength in community-dwelling older adults: the Tasmanian older adult cohort study. J Am Geriatr Soc 58, 2129-2134.

35. Geirsdottir OG, Arnarson A, Ramel A, et al. (2013) Dietary protein intake is associated with lean body mass in community-dwelling older adults. Nutr Res 33, 608-612.

36. McDonald CK, Ankarfeldt MZ, Capra S, et al. (2016) Lean body mass change over 6 years is associated with dietary leucine intake in an older Danish population. Br J Nutr 115, 1556-1562.

37. Chan R, Leung J, Woo J, et al. (2014) Associations of dietary protein intake on subsequent decline in muscle mass and physical functions over four years in ambulant older Chinese people. J Nutr Health Aging 18, 171-177.

38. Gregorio L, Brindisi J, Kleppinger A, et al. (2014) Adequate dietary protein is associated with better physical performance among post-menopausal women $60-90$ years. J Nutr Health Aging 18, 155-160.

39. Mangano KM, Sahni S, Kiel DP, et al. (2017) Dietary protein is associated with musculoskeletal health independently of dietary pattern: the Framingham third generation study. Am J Clin Nutr 105, 714-722.

40. Verreijen AM, Engberink MF, Houston DK, et al. (2019) Dietary protein intake is not associated with 5-years change in mid-thigh muscle cross-sectional area by computed tomography in older adults: the health, aging, and body composition (Health ABC) study. Am J Clin Nutr 109, 535-543.

41. Højfeldt G, Nishimura Y, Mertz K, et al. (2020) Daily protein and energy intake are not associated with muscle mass and physical function in healthy older individuals - a crosssectional study. Nutrients 12, 2794.

42. Sahni S, Mangano KM, Hannan MT, et al. (2015) Higher protein intake is associated with higher lean mass and quadriceps muscle strength in adult men and women. J Nutr 145, 1569-1575.

43. Kerstetter JE, Bihuniak JD, Brindisi J, et al. (2015) The effect of a whey protein supplement on bone mass in older Caucasian adults. J Clin Endocrinol Metab 100, 2214-2222.
44. Zhu K, Kerr DA, Meng X, et al. (2015) Two-year whey protein supplementation did not enhance muscle mass and physical function in well-nourished healthy older postmenopausal women. J Nutr 145, 2520-2526.

45. Norton C, Toomey C, McCormack WG, et al. (2016) Protein supplementation at breakfast and lunch for 24 weeks beyond habitual intakes increases whole-body lean tissue mass in healthy older adults. J Nutr 146, 65-69.

46. Mitchell CJ, Milan AM, Mitchell SM, et al. (2017) The effects of dietary protein intake on appendicular lean mass and muscle function in elderly men: a 10-week randomized controlled trial. Am J Clin Nutr 106, 1375-1383.

47. Ten Haaf DSM, Eijsvogels TMH, Bongers C, et al. (2019) Protein supplementation improves lean body mass in physically active older adults: a randomized placebo-controlled trial. J Cachexia Sarcopenia Muscle 10, 298-310.

48. Mertz KH, Reitelseder S, Bechshoeft R, et al. (2021) The effect of daily protein supplementation, with or without resistance training for 1 year, on muscle size, strength, and function in healthy older adults: a randomized controlled trial. $A m J$ Clin Nutr 113, 790-800.

49. Bauer J, Biolo G, Cederholm T, et al. (2013) Evidence-based recommendations for optimal dietary protein intake in older people: a position paper from the PROT-AGE study group. J Am Med Dir Assoc 14, 542-559.

50. Deutz NE, Bauer JM, Barazzoni R, et al. (2014) Protein intake and exercise for optimal muscle function with aging: recommendations from the ESPEN expert group. Clin Nutr 33, 929-936.

51. Nordic Council of Ministers (2014) Nordic Nutrition Recommendations 2012: Integrating Nutrition and Physical Activity. Copenhagen: Nordic Council of Ministers.

52. Højfeldt G, Bülow J, Agergaard J, et al. (2020) Impact of habituated dietary protein intake on fasting and postprandial whole-body protein turnover and splanchnic amino acid metabolism in elderly men: a randomized, controlled, crossover trial. Am J Clin Nutr 112, 1468-1484.

53. Halliday D \& McKeran RO (1975) Measurement of muscle protein synthetic rate from serial muscle biopsies and total body protein turnover in man by continuous intravenous infusion of L- $(\alpha-15 \mathrm{~N})$ lysine. Clin Sci Mol Med 49, 581-590.

54. Wolfe RR \& Chinkes DL (2004) Isotope Tracers in Metabolic Research: Principles and Practice of Kinetic Analysis. Hoboken, NJ: John Wiley \& Sons.

55. Kim IY, Suh SH, Lee IK, et al. (2016) Applications of stable, nonradioactive isotope tracers in in vivo human metabolic research. Exp Mol Med 48, e203.

56. Wilkinson DJ (2016) Historical and contemporary stable isotope tracer approaches to studying mammalian protein metabolism. Mass Spectrom Rev 47, 987-992.

57. Wilkinson DJ, Brook MS, Smith K, et al. (2016) Stable isotope tracers and exercise physiology: past, present and future. J Physiol 595, 2873-2882.

58. Wilkinson DJ, Brook MS \& Smith K (2021) Principles of stable isotope research-with special reference to protein metabolism. Clin Nutr Open Sci 36, 111-125.

59. Nair KS, Halliday D \& Griggs RC (1988) Leucine incorporation into mixed skeletal muscle protein in humans. Am J Physiol 254, E208-E213.

60. Deutz NE, Wagenmakers AJ \& Soeters PB (1999) Discrepancy between muscle and whole body protein turnover. Curr Opin Clin Nutr Metab Care 2, 29-32.

61. Bohe J, Low A, Wolfe RR, et al. (2003) Human muscle protein synthesis is modulated by extracellular, not intramuscular 
amino acid availability: a dose-response study. J Physiol 552, 315-324.

62. Moore DR, Churchward-Venne TA, Witard O, et al. (2015) Protein ingestion to stimulate myofibrillar protein synthesis requires greater relative protein intakes in healthy older $v$. younger men. J Gerontol A Biol Sci Med Sci 70, 57-62.

63. Cuthbertson D, Smith K, Babraj J, et al. (2005) Anabolic signaling deficits underlie amino acid resistance of wasting, aging muscle. FASEB J 19, 422-424.

64. Yang Y, Breen L, Burd NA, et al. (2012) Resistance exercise enhances myofibrillar protein synthesis with graded intakes of whey protein in older men. Br J Nutr 108, 1780-1788.

65. Witard OC, Jackman SR, Breen L, et al. (2013) Myofibrillar muscle protein synthesis rates subsequent to a meal in response to increasing doses of whey protein at rest and after resistance exercise. Am J Clin Nutr 99, 86-95.

66. Bohe J, Low JF, Wolfe RR, et al. (2001) Latency and duration of stimulation of human muscle protein synthesis during continuous infusion of amino acids. J Physiol 532, 575-579.

67. Atherton PJ, Etheridge T, Watt PW, et al. (2010) Muscle full effect after oral protein: time-dependent concordance and discordance between human muscle protein synthesis and mTORC1 signaling. Am J Clin Nutr 92, 1080-1088.

68. Bechshoeft R, Dideriksen KJ, Reitelseder S, et al. (2013) The anabolic potential of dietary protein intake on skeletal muscle is prolonged by prior light-load exercise. Clin Nutr 32, 236-244.

69. Balagopal P, Rooyackers OE, Adey DB, et al. (1997) Effects of aging on in vivo synthesis of skeletal muscle myosin heavy-chain and sarcoplasmic protein in humans. Am J Physiol 273, E790-E800.

70. Yarasheski KE, Zachwieja JJ \& Bier DM (1993) Acute effects of resistance exercise on muscle protein synthesis rate in young and elderly men and women. Am J Physiol 265, E210-E214.

71. Welle S, Thornton C, Jozefowicz R, et al. (1993) Myofibrillar protein synthesis in young and old men. Am J Physiol 264, E693-E698.

72. Volpi E, Sheffield-Moore M, Rasmussen BB, et al. (2001) Basal muscle amino acid kinetics and protein synthesis in healthy young and older men. JAMA 286, 1206-1212.

73. Hirsch KR, Church DD, Kim IY, et al. (2020) Comparison of basal whole-body protein kinetics and muscle protein synthesis between young and older adults. Physiol Rep $\mathbf{8}$, e14633.

74. Katsanos CS, Kobayashi H, Sheffield-Moore M, et al. (2005) Aging is associated with diminished accretion of muscle proteins after the ingestion of a small bolus of essential amino acids. Am J Clin Nutr 82, 1065-1073.

75. Shad BJ, Thompson JL \& Breen L (2016) Does the muscle protein synthetic response to exercise and amino acid-based nutrition diminish with advancing age? A systematic review. Am J Physiol Endocrinol Metab 311, E803-E817.

76. Wall BT, Gorissen SH, Pennings B, et al. (2015) Aging is accompanied by a blunted muscle protein synthetic response to protein ingestion. PLOS ONE 10, e0140903.

77. Phillips SM \& Martinson W (2019) Nutrient-rich, high-quality, protein-containing dairy foods in combination with exercise in aging persons to mitigate sarcopenia. Nutr Rev 77, 216-229.

78. Symons TB, Schutzler SE, Cocke TL, et al. (2007) Aging does not impair the anabolic response to a protein-rich meal. $A m J$ Clin Nutr 86, 451-456.

79. Burd NA, Gorissen SH, van Vliet S, et al. (2015) Differences in postprandial protein handling after beef compared with milk ingestion during postexercise recovery: a randomized controlled trial. Am J Clin Nutr 102, 828-836.
80. van Vliet S, Shy EL, Abou Sawan S, et al. (2017) Consumption of whole eggs promotes greater stimulation of postexercise muscle protein synthesis than consumption of isonitrogenous amounts of egg whites in young men. Am J Clin Nutr 106, 1401-1412.

81. Kim IY, Shin YA, Schutzler SE, et al. (2017) Quality of meal protein determines anabolic response in older adults. Clin Nutr 37, 2076-2083.

82. Kim IY, Schutzler S, Schrader A, et al. (2016) The anabolic response to a meal containing different amounts of protein is not limited by the maximal stimulation of protein synthesis in healthy young adults. Am J Physiol Endocrinol Metab 310, E73-E80.

83. Park S, Jang J, Choi MD, et al. (2020) The anabolic response to dietary protein is not limited by the maximal stimulation of protein synthesis in healthy older adults: a randomized crossover trial. Nutrients 12, 3276.

84. Kim IY, Schutzler S, Schrader AM, et al. (2018) Protein intake distribution pattern does not affect anabolic response, lean body mass, muscle strength or function over 8 weeks in older adults: a randomized-controlled trial. Clin Nutr 37, 488-493.

85. Deutz NE \& Wolfe RR (2013) Is there a maximal anabolic response to protein intake with a meal? Clin Nutr 32, 309-313.

86. Gelfand RA \& Barrett EJ (1987) Effect of physiologic hyperinsulinemia on skeletal muscle protein synthesis and breakdown in man. J Clin Invest $\mathbf{8 0}, 1-6$.

87. Tessari P, Inchiostro S, Biolo G, et al. (1991) Effects of acute systemic hyperinsulinemia on forearm muscle proteolysis in healthy man. J Clin Invest 88, 27-33.

88. Reitelseder S, Tranberg B, Agergaard J, et al. (2020) Phenylalanine stable isotope tracer labeling of cow milk and meat and human experimental applications to study dietary protein-derived amino acid availability. Clin Nutr 39, 3652-3662.

89. Wilkes EA, Selby AL, Atherton PJ, et al. (2009) Blunting of insulin inhibition of proteolysis in legs of older subjects may contribute to age-related sarcopenia. Am J Clin Nutr $\mathbf{9 0}$, 1343-1350.

90. Rasmussen BB, Fujita S, Wolfe RR, et al. (2006) Insulin resistance of muscle protein metabolism in aging. FASEB $J$ 20, 768-769.

91. Groen BB, Horstman AM, Hamer HM, et al. (2016) Increasing insulin availability does not augment postprandial muscle protein synthesis rates in healthy young and older men. J Clin Endocrinol Metab 101, 3978-3988.

92. Abdulla H, Smith K, Atherton PJ, et al. (2016) Role of insulin in the regulation of human skeletal muscle protein synthesis and breakdown: a systematic review and meta-analysis. Diabetologia 59, 44-55.

93. Trommelen J, Groen BB, Hamer HM, et al. (2015) mechanisms in endocrinology: exogenous insulin does not increase muscle protein synthesis rate when administered systemically: a systematic review. Eur J Endocrinol 173, R25-R34.

94. Joint FAO/WHO Ad hoc Expert Committee on Energy and Protein Requirements, World Health Organization \& Food and Agriculture Organization of the United Nations (1973) Energy and Protein Requirements: Report of a Joint FAO/ WHO Ad hoc Expert Committee (Meeting Held in Rome from 22 March to 2 April 1971). Geneva: World Health Organization.

95. Joint FAO/WHO/UNU Expert Consultation on Energy and Protein Requirements, Food and Agriculture Organization of the United Nations, World Health Organization, et al. (1985) Energy and Protein Requirements: Report of a Joint FAO/WHO/UNU Expert Consultation (Held in Rome from 5 to 17 October 1981). Geneva: World Health Organization. 
96. Millward DJ (2004) Macronutrient intakes as determinants of dietary protein and amino acid adequacy. J Nutr 134, 1588S-1596S.

97. Beattie J, Herbert PH \& Bell D (1947) Nitrogen balances during recovery from severe undernutrition. Br J Nutr 1, 202-219.

98. Calloway DH \& Spector H (1954) Nitrogen balance as related to caloric and protein intake in active young men. Am J Clin Nutr 2, 405-412.

99. Munro HN (1978) Energy and protein intakes as determinants of nitrogen balance. Kidney Int 14, 313-316.

100. Carbone JW, McClung JP \& Pasiakos SM (2012) Skeletal muscle responses to negative energy balance: effects of dietary protein. Adv Nutr 3, 119-126.

101. Pasiakos SM, Margolis LM \& Orr JS (2015) Optimized dietary strategies to protect skeletal muscle mass during periods of unavoidable energy deficit. FASEB J 29, 1136-1142.

102. Carbone JW, McClung JP \& Pasiakos SM (2018) Recent advances in the characterization of skeletal muscle and whole-body protein responses to dietary protein and exercise during negative energy balance. Adv Nutr 10, 70-79.

103. Carbone JW, Margolis LM, McClung JP, et al. (2013) Effects of energy deficit, dietary protein, and feeding on intracellular regulators of skeletal muscle proteolysis. FASEB $J$ 27, 5104-5111.

104. Pasiakos SM, Cao JJ, Margolis LM, et al. (2013) Effects of highprotein diets on fat-free mass and muscle protein synthesis following weight loss: a randomized controlled trial. FASEB J 27, 3837-3847.

105. Pasiakos SM, Margolis LM, McClung JP, et al. (2014) Wholebody protein turnover response to short-term high-protein diets during weight loss: a randomized controlled trial. Int J Obes 38, 1015-1018.

106. Piatti P, Monti L, Magni F, et al. (1994) Hypocaloric highprotein diet improves glucose oxidation and spares lean body mass: comparison to hypocaloric high-carbohydrate diet. Metab Clin Exp 43, 1481-1487.

107. Leidy HJ, Carnell NS, Mattes RD, et al. (2007) Higher protein intake preserves lean mass and satiety with weight loss in pre-obese and obese women. Obesity 15, 421-429.

108. Mojtahedi MC, Thorpe MP, Karampinos DC, et al. (2011) The effects of a higher protein intake during energy restriction on changes in body composition and physical function in older women. J Gerontol A Biomed Sci Med Sci 66, 1218-1225.

109. Wycherley TP, Moran LJ, Clifton PM, et al. (2012) Effects of energy-restricted high-protein, low-fat compared with standard-protein, low-fat diets: a meta-analysis of randomized controlled trials. Am J Clin Nutr 96, 1281-1298.

110. Berryman CE, Young AJ, Karl JP, et al. (2017) Severe negative energy balance during $21 \mathrm{~d}$ at high altitude decreases fat-free mass regardless of dietary protein intake: a randomized controlled trial. FASEB J 32, 894-905.

111. Woolfson A (1983) Amino acids - their role as an energy source. Proc Nutr Soc 42, 489-495.

112. Bray GA, Smith SR, de Jonge L, et al. (2012) Effect of dietary protein content on weight gain, energy expenditure, and body composition during overeating: a randomized controlled trial. JAMA 307, 47-55.

113. Waterlow J (1986) Metabolic adaptation to low intakes of energy and protein. Annu Rev Nutr 6, 495-526.

114. Waterlow J (1990) Nutritional adaptation in man: general introduction and concepts. Am J Clin Nutr 51, 259-263.

115. Young VR (1987) 1987 McCollum award lecture. Kinetics of human amino acid metabolism: nutritional implications and some lessons. Am J Clin Nutr 46, 709-725.

116. Gorissen SH, Horstman AM, Franssen R, et al. (2017) Habituation to low or high protein intake does not modulate basal or postprandial muscle protein synthesis rates: a randomized trial. Am J Clin Nutr 105, 332-342.

117. Walrand S, Short KR, Bigelow ML, et al. (2008) Functional impact of high protein intake on healthy elderly people. Am J Physiol Endocrinol Metab 295, E921-E928.

118. Millward D (2003) An adaptive metabolic demand model for protein and amino acid requirements. Br J Nutr $\mathbf{9 0}$, 249-260.

119. Millward DJ \& Smith K (2018) The application of stable-isotope tracers to study human musculoskeletal protein turnover: a tale of bag filling and bag enlargement. J Physiol 597, 1235-1249.

120. Holm L \& Nordsborg NB (2017) Supplementing a normal diet with protein yields a moderate improvement in the robust gains in muscle mass and strength induced by resistance training in older individuals. Am J Clin Nutr 106, 971-972.

121. Ten Haaf DSM, Nuijten MAH, Maessen MFH, et al. (2018) Effects of protein supplementation on lean body mass, muscle strength, and physical performance in non-frail communitydwelling older adults: a systematic review and meta-analysis. Am J Clin Nutr 108, 1043-1059.

122. Hengeveld LM, Boer JMA, Gaudreau P, et al. (2020) Prevalence of protein intake below recommended in community-dwelling older adults: a meta-analysis across cohorts from the PROMISS consortium. J Cachexia Sarcopenia Muscle 11, $1212-1222$

123. Glista W, Mitchell H \& Scott H (1951) The amino acid requirements of the chick. Poultr Sci 30, 915.

124. Fisher H \& Scott HM (1954) The essential amino acid requirements of chicks as related to their proportional occurrence in the fat free carcass. Arch Biochem Biophys 51, 517-519.

125. Wu G (2014) Dietary requirements of synthesizable amino acids by animals: a paradigm shift in protein nutrition. J Anim Sci Biotechnol 5, 34 .

126. Eggum BO (1973) A Study of Certain Factors Influencing Protein Utilization in Rats and Pigs. Report no. 406. Copenhagen: National Institute of Animal Science.

127. Wolfe RR, Rutherfurd SM, Kim IY, et al. (2016) Protein quality as determined by the digestible indispensable amino acid score: evaluation of factors underlying the calculation. Nutr Rev 74, 584-599.

128. Tessari P (2019) Are there dietary requirements for dispensable amino acids and if so, how do we assess requirements? Curr Opin Clin Nutr Metab Care 22, 329-336.

129. Lee WT, Weisell R, Albert J, et al. (2016) Research approaches and methods for evaluating the protein quality of human foods proposed by an FAO expert working group in 2014. J Nutr 146, 929-932.

130. Marinangeli CP \& House JD (2017) Potential impact of the digestible indispensable amino acid score as a measure of protein quality on dietary regulations and health. Nutr Rev 75, 658-667.

131. Tilman D \& Clark M (2014) Global diets link environmental sustainability and human health. Nature $\mathbf{5 1 5}, 518-522$.

132. Burd NA, McKenna CF, Salvador AF, et al. (2019) Dietary protein quantity, quality, and exercise are key to healthy living: a muscle-centric perspective across the lifespan. Front Nutr 6, 83.

133. Dinu M, Abbate R, Gensini GF, et al. (2017) Vegetarian, vegan diets and multiple health outcomes: a systematic review with meta-analysis of observational studies. Crit Rev Food Sci Nutr 57, 3640-3649.

134. Norman K \& Klaus S (2020) Veganism, aging and longevity: new insight into old concepts. Curr Opin Clin Nutr Metab Care 23, 145-150. 
135. Lord C, Chaput J, Aubertin-Leheudre M, et al. (2007) Dietary animal protein intake: association with muscle mass index in older women. J Nutr Health Aging 11, 383.

136. Gorissen SHM \& Witard OC (2017) Characterising the muscle anabolic potential of dairy, meat and plant-based protein sources in older adults. Proc Nutr Soc 77, 20-31.

137. Katsanos CS, Kobayashi H, Sheffield-Moore M, et al. (2006) A high proportion of leucine is required for optimal stimulation of the rate of muscle protein synthesis by essential amino acids in the elderly. Am J Physiol Endocrinol Metab 291, E381-E387.

138. Wall BT, Hamer HM, de Lange A, et al. (2013) Leucine co-ingestion improves post-prandial muscle protein accretion in elderly men. Clin Nutr 32, 412-419.

139. Roberts SB \& Dallal GE (2005) Energy requirements and aging. Public Health Nutr 8, 1028-1036.

140. Joint FAO/WHO Expert Group on Protein Requirements, World Health Organization \& Food and Agriculture Organization of the United Nations (1965) Protein Requirements: Report of a Joint FAO/WHO Expert Group (Meeting Held in Geneva from 8 to 17 October 1963). Geneva: World Health Organization.

141. Scrimshaw NS (1996) Human protein requirements: a brief update. Food Nutr Bull 17, 1-7.

142. Capra S (2006) Nutrient Reference Values for Australia and New Zealand: Including Recommended Dietary Intakes. Canberra: National Health and Medical Research Council.
143. Campbell W, Evans W (1996) Protein requirements of elderly people. Eur J Clin Nutr 50, S180.

144. Campbell WW, Trappe TA, Wolfe RR, et al. (2001) The recommended dietary allowance for protein may not be adequate for older people to maintain skeletal muscle. J Gerontol A Biol Sci Med Sci 56, M373-M380.

145. Pedersen AN \& Cederholm T (2014) Health effects of protein intake in healthy elderly populations: a systematic literature review. Food Nutr Res 58, 23364.

146. Moore DR, Tang JE, Burd NA, et al. (2009) Differential stimulation of myofibrillar and sarcoplasmic protein synthesis with protein ingestion at rest and after resistance exercise. J Physiol 587, 897-904.

147. Breen L, Stokes KA, Churchward-Venne TA, et al. (2013) Two weeks of reduced activity decreases leg lean mass and induces "anabolic resistance" of myofibrillar protein synthesis in healthy elderly. J Clin Endocrinol Metab 98, 2604-2612.

148. Burd NA, West DW, Moore DR, et al. (2011) Enhanced amino acid sensitivity of myofibrillar protein synthesis persists for up to $24 \mathrm{~h}$ after resistance exercise in young men. $J$ Nutr $\mathbf{1 4 1}$, $568-573$.

149. Churchward-Venne TA, Burd NA, Mitchell CJ, et al. (2012) Supplementation of a suboptimal protein dose with leucine or essential amino acids: effects on myofibrillar protein synthesis at rest and following resistance exercise in men. J Physiol 590, 2751-2765.

150. Kim I-Y, Deutz NEP \& Wolfe RR (2017) Update on maximal anabolic response to dietary protein. Clin Nutr 37, 411-418. 